\title{
Highly Dense and Chemically Stable Proton Conducting Electrolyte Sintered at
}

\section{$1200{ }^{\circ} \mathrm{C}$}

Shahzad Hossain $^{\text {a,b,c,* }}$, Abdalla M. Abdalla ${ }^{\mathrm{a}, \mathrm{c}, \mathrm{d}}$, Nikdalila Radenahmad ${ }^{\mathrm{a}}$, A. K. M. Zakaria ${ }^{\mathrm{b}}$, Juliana H. Zaini ${ }^{\text {a }}$, S. M. Habibur Rahman ${ }^{\mathrm{e}}$, Sten G. Eriksson ${ }^{\mathrm{e}}$, John T. S. Irvine ${ }^{\mathrm{c}}$, Abul K. Azad ${ }^{\mathrm{a},{ }^{*}}$

${ }^{a}$ Faculty of Integrated Technologies, Universiti Brunei Darussalam, Jalan Tungku Link, Gadong, BE 1410, Brunei Darussalam

${ }^{b}$ Institute of Nuclear Science and Technology, Bangladesh Atomic Energy Commission, GPO Box No. 3787, Dhaka 1000, Bangladesh

${ }^{c}$ Center for Advanced Materials, School of Chemistry, University of St Andrews, Fife KY16 9ST, Scotland, $U K$

${ }^{d}$ Department of Mechanical Engineering, Faculty of Engineering, Suez Canal University, Ismailia 41522, Egypt

${ }^{e}$ Department of Chemistry and Chemical Engineering, Chalmers University of Technology, Goteborg, SE 41296, Sweden

*Corresponding authors: Email: shahzad_baec@yahoo.com,abul.azad@@ubd.edu.bn Phone: +8801712190600, +6737219025

\begin{abstract}
The $\mathrm{BaCe}_{0.7} \mathrm{Zr}_{0.1} \mathrm{Y}_{0.2-\mathrm{x}} \mathrm{Zn}_{\mathrm{x}} \mathrm{O}_{3-\delta}(\mathrm{x}=0.05,0.10,0.15,0.20)$ has been synthesized by the conventional solid state reaction method for application in protonic solid oxide fuel cell. The phase purity and lattice parameters of the materials have been studied by the room temperature $\mathrm{X}$-ray diffraction (XRD). Scanning electron microscopy (SEM) has been done for check the morphology and grain growth of the samples. The chemical and mechanical stabilities have been done using thermogravimetric analysis (TGA) in pure $\mathrm{CO}_{2}$ environment and thermomechanical analysis
\end{abstract}


(TMA) in Argon atmosphere. The XRD of the materials show the orthorhombic crystal symmetry with Pbnm space group. The SEM images of the pellets show that the samples sintered at $1200^{\circ} \mathrm{C}$ are highly dense. The XRD after TGA in $\mathrm{CO}_{2}$ and thermal expansion measurements confirm the stability. The particles of the samples are in micrometer ranges and increasing $\mathrm{Zn}$ content decreases the size. The conductivity measurements have been done in $5 \% \mathrm{H}_{2}$ with $\mathrm{Ar}$ in dry and wet atmospheres. All the materials show high proton conductivity in the intermediate temperature range (400-700 ${ }^{\circ} \mathrm{C}$ ). The maximum proton conductivity was found to be $1.0 \times 10^{-2} \mathrm{~S} \mathrm{~cm}^{-1}$ at $700^{\circ} \mathrm{C}$ in wet atmosphere for $\mathrm{x}=0.10$. From our study, $10 \mathrm{wt} \%$ of $\mathrm{Zn}$ seems to be optimum at the B-site of the perovskite structure. All the properties studied here suggest it can be a promising candidate of electrolyte for IT-SOFCs.

Keywords: Perovskite; Proton conductor; Rietveld refinement; Electrolyte; Chemical stability; Impedance analysis.

\section{Introduction}

Fuel cells have very good impact to resolve the present energy demands in the world. Solid oxide fuel cells (SOFCs) operate at intermediate temperature have attracted much interest worldwide because of their affordability, prospective long term stability and wide range of applications (including accommodation and transports) [1]-[3]. In the modern ages, the proton conducting electrolytes get a great enhancement in SOFCs technologies operating in intermediate temperatures. For an extensive range of technological applications such as batteries, gas and humidity sensors, separators, supercapacitors, fuel cells, hydrogenation or dehydrogenation of hydrocarbon electrolysers, there are increasing interests in proton-conducting electrolytes for SOFCs [1]-[7]. At a temperature below $600^{\circ} \mathrm{C}$, doped ceria based materials potentially meet the utmost necessities for fuel-cell operation, appears to be the best available electrolyte materials [4], [8]-[9]. Though, 
comprising the protonic conductivity and indeterminate perfunctory of reliability below the fuelcell working conditions some significant issues are still remain challenges. The electrolyte operates at low temperature show very potential candidate because of their low activation energy (AE) of protons conduction. Many perovskite-type oxides show elevated proton conductivity in reducing atmosphere [10]-[13] but the compromise between conductivity and chemical stability is the most substantial challenges for those type of materials [14]-[16].

The barium cerates $\left(\mathrm{BaCeO}_{3}\right)$ based materials exhibit mixed ionic (protons and oxide ions) conduction [17], [18] as electrolytes. These materials show good sintering behavior and elevated ionic (proton) conductivity [11], [19] however they are unstable under steam and $\mathrm{CO}_{2}$ conditions lead to destroying the perovskite structure [20], [21]. On the other hand the zirconates $\left(\mathrm{BaZrO}_{3}\right)$ do not sinter easily, and the maximum conductivities are only found when sintering occurs at or approaching $1700{ }^{\circ} \mathrm{C}$ [22]. Even after sintering at very high temperatures, the very poor grainboundary conductivity of these materials is a main problem; these materials do not provide appropriate performance for practical application. Although, the crystal component is difficult to resolve in polycrystalline samples, it does seem that this is only improved when heated at very high temperatures, above of $1600{ }^{\circ} \mathrm{C}$. This appears to indicate that reaching of the utmost conductivities is influenced by some form of phase transformation or segregation or, as suggested by Snijkers et al. [23] by a slow kinetic process of water absorption.

The formation of solid solutions between $\mathrm{BaCeO}_{3}$ and $\mathrm{BaZrO}_{3}$ are comparably easily occurring. It is also possible to form a solid solution by replacing a desired fraction of $\mathrm{Ce}$ in $\mathrm{BaCeO}_{3}$ with $\mathrm{Zr}$ and other element that exhibit both sufficient proton conductivity as well as adequate chemical and thermal stability over a wider variety of conditions appropriate to fuel cell operation [10], [16], [21], [24]-[28]. It was found that doped zirconates gives improved chemical stability but reduced protonic conductivity compared to the doped cerates. To accomplish elevated ionic conductivity as well as sufficient chemical and thermal stability, the stability of doped barium cerates can be 
improved by doping of $\mathrm{Zr}$ at the B-site. But still it is difficult to develop the electrolyte material with low sintering temperature and high density which is very essential in SOFCs operation. The effect of Ba non-stoichiometry and $\mathrm{Cr}$ deposition, poisoning were studied on the $\mathrm{Zr}$, Y co-doped $\mathrm{BaCeO}_{3}$ based proton conductors and showed that the $\mathrm{Ba}$ non-stoichiometry influenced the electrical conductivity, especially with respect to grain boundary resistance and the $\mathrm{Cr}$ poisoning effect of the electrochemical performance of BZCY electrolyte [29], [30].

Despite the fact that the sintering temperature was still very high [31], recently the partial substitution of $\mathrm{Zr}^{+4}$ cation into $\mathrm{Ce}^{+4}$ cation was reported as an electrolyte material and it was found the improved chemical stability [32], [33]. It was a great challenge to process electrolyte material at low temperature to get desired result such as high conductivity, high density and chemical stability. At high temperature sintering with long time heat treatment can be predicted the barium oxide evaporation and thereby decrease the conductivity, as has been detected in $\mathrm{BaCeO}_{3}$ [32], . But in the solid state synthesis using the barium excess of $\geq 10 \mathrm{~mol} \%$ led to a higher conductivity [34]. It is found among the perovskite oxides that doped barium cerates exhibit mixed oxide and proton ion conductivity [35] upon exposure to stream atmospheres. However, it is difficult to get high density of doped barium cerate or zirconate materials at a sintering temperature below $1400{ }^{\circ} \mathrm{C}$. Getting theoretical density above $90 \%$ of the material we need to sinter at high temperature (above $1400{ }^{\circ} \mathrm{C}$ ) where Ba could evaporate to a certain degree [22], [36]. To decrease the sintering temperature of ceramics materials, applying a sintering aid is one of the most effective ways [37][38]. In the previous years, to improve the sinterability of ceramic proton conductors, researchers have tried with different additives. The effect of $\mathrm{MO}_{\mathrm{x}}$ metal oxides (where $\mathrm{M}=\mathrm{Ti}, \mathrm{Fe}, \mathrm{Co}, \mathrm{Ni}, \mathrm{Cu}$, $\mathrm{Zn}$ ) on the densification behavior found that the addition of small amounts of these metal oxides could lower the sintering temperature by $150-250{ }^{\circ} \mathrm{C}$ [38]. Further studies showed that the $\mathrm{Cu}$ and Zn containing materials have significantly higher conductivity than the others in both moistened air and humidified hydrogen atmospheres. However, adding of $\mathrm{CuO}$ led to the formation of a 
$\mathrm{Ba}_{2} \mathrm{YCu}_{3} \mathrm{O}_{\mathrm{x}}$ impurity phase [39]. On the other hand, under a reduced atmosphere the decrease of $\mathrm{CuO}$ to metallic copper is a large anxiety in practical fuel cell applications. Therefore, as a sintering aid $\mathrm{ZnO}$ in doped $\mathrm{BaCeO}_{3}-\mathrm{BaZrO}_{3}$, is the most encouraging metallic oxide. Formerly, the sintering behavior of proton conductors with $\mathrm{ZnO}$ as a sintering aid was investigated by many researchers [38], [39]-[43]. Most of those researchers usually examined the sintering behavior of thick pellets [38], [39], [41]-[43] but applying such electrolytes in real fuel cell fabrication was rare.

In order to solve the density and high sintering temperature issues, $\mathrm{Zn}$ was introduced into $\mathrm{Y}$ and $\mathrm{Zr}$ co-doped $\mathrm{BaCeO}_{3}$ [39]-[41]. In 2005, Balibo and Haile first reported that $\mathrm{ZnO}$ is an excellent sintering aid for yttrium-doped $\mathrm{BaZrO}_{3}$, lowering the densification temperature from $1700{ }^{\circ} \mathrm{C}$ to $1300{ }^{\circ} \mathrm{C}$ [39]. In 2006, Tao and Irvine found that the introduction of small amount of $\mathrm{Zn}^{2+}$ substituted for $\mathrm{Y}^{3+}$ at $\mathrm{B}$ site into the perovskite structure allows a reduction in high sintering temperatures and a notable progress in the stability, relative density and conductivity [41]. Slodczyk and Sharp showed that Zn doped Barium Cerium Zirconium Yttrium oxide (BCZYZn) has been offering the benefits of both stability and elevated proton conductivity [18] as potential high performance proton conductor. Our group reported [11] by co-doping of $\mathrm{Zr}, \mathrm{Sc}$ and $\mathrm{Zn}$ in the lattice displayed the stable proton-conducting electrolyte $\mathrm{BaCe}_{0.5} \mathrm{Zr}_{0.35} \mathrm{Sc}_{0.1} \mathrm{Zn}_{0.05} \mathrm{O}_{3-\delta}$, sintered at lower temperature which was dense and showed the enhanced chemical stability. Iwahara reported that these oxides also exhibit mixed proton and oxide ion conductivity upon exposure to humid atmosphere [20]. Proton conductivity can be significantly improved by doping various rare earth ions such as Y, Yb, Eu, Gd, Nd, etc. or using Sr [14], [21-26], [44-46] . Recently, we have proved that $\mathrm{Zn}$ doped Barium Cerium Zirconium Yttrium Oxide (BCZYZn) offers high proton conductivity and high stability as being electrolyte for proton conducting SOFCs [47]. As the physical and electrochemical property of materials depends on the composition, we worked on other compositions with Zn-doping. 
In this report, $\mathrm{BaCe}_{0.7} \mathrm{Zr}_{0.1} \mathrm{Y}_{0.2-\mathrm{x}} \mathrm{Zn}_{\mathrm{x}} \mathrm{O}_{3-\delta}(\mathrm{x}=0.05,0.10,0.15$ and 0.20$)$, a series of new compositions were prepared; where zirconium, yttrium and zinc were substituted with cerium in B site at different percentages. The single phase compositions were prepared at a lower temperature than other similar materials reported in the literatures and their structural, thermal and electrochemical properties were investigated. The oxygen vacancies facilitates the proton conductivity, therefore, by acceptor doping, i.e., doping by lower valance cations at the B-site, i.e. yttrium and zinc, these vacancies can be significantly increased.

Different synthesis processes were followed to develop different elements dopants in $\mathrm{BaCeO}_{3}$ reports [48], [49] and another report [50] showed the influence of $\mathrm{ZnO}$ addition on the properties of high temperature proton conductor $\mathrm{Ba}_{1.03} \mathrm{Ce}_{0.5} \mathrm{Zr}_{0.4} \mathrm{Y}_{0.1} \mathrm{O}_{3-\delta}$ synthesized via citrate-nitrate method. The series of perovskite type compounds, $\mathrm{BaCe}_{0.7} \mathrm{Zr}_{0.1} \mathrm{Y}_{0.2-\mathrm{x}} \mathrm{Zn}_{\mathrm{x}} \mathrm{O}_{3-\delta}$ were prepared by solid state reaction method and this method was adopted because of its simplicity and low cost. Many researchers including us have used the solid state reaction method to developed oxide materials for IT-SOFCs [17], [51]. In this study we have varied the weight percent of $\mathrm{Zn}$ instead of $\mathrm{Y}$ to find the optimum percentage of $\mathrm{Zn}$ doping and the structural, physical and electrochemical properties were investigated to find their potential use in IT-SOFCs.

\section{Experimental}

\subsection{Synthesis of the materials}

The $\mathrm{BaCe}_{0.7} \mathrm{Zr}_{0.1} \mathrm{Y}_{0.2-\mathrm{x}} \mathrm{Zn}_{\mathrm{x}} \mathrm{O}_{3-\delta}$ samples $(\mathrm{x}=0.05,0.10,0.15$ and 0.20, named as BCZYZ 1, BCZYZ 2, BCZYZ 3 and BCZYZ 4, respectively) were prepared by the conventional solid state reaction method. The highest sintering temperature was done at $1200{ }^{\circ} \mathrm{C}$ in air for 12 hours inside a muffle furnace. The powder chemicals of $\mathrm{BaCO}_{3}, \mathrm{CeO}_{2}, \mathrm{ZrO}_{2}, \mathrm{Y}_{2} \mathrm{O}_{3}$ and $\mathrm{ZnO}$ (purity were stated as more than $99.95 \%$ ) as initial ingredients were used in exact stoichiometric amounts, supplied from the 
company Sigma Aldrich. The ingredients were preheated at $200{ }^{\circ} \mathrm{C}$ for 2 hours and quickly after that weighed individually to avoid re-carbonation, using a precise digital micro balance and then thoroughly mixed in an agate mortar for one hour of each with small amount of ethanol. The samples were then milled intimately using a ball-mill machine for about 4 hours of each with suitable quantity of deionized water and then heated on a magnetic heater until dry. The samples were then grinded and heated inside a muffle furnace at $900{ }^{\circ} \mathrm{C}$ for 12 hours with heating and cooling rate of $5{ }^{\circ} \mathrm{C} / \mathrm{min}$ for calcination. The calcined samples were reground and remixed in a mortar pestle for one hour of each and then pellets of $13 \mathrm{~mm}$ dia (about $2 \mathrm{gm} / \mathrm{each}$ ) were pressed under the hydraulic press with 3-4 ton pressure and heated at $1050{ }^{\circ} \mathrm{C}$ for 10 hours. The XRD scans were done on the samples to check the reaction and phase purity after heated at $1050{ }^{\circ} \mathrm{C}$. The grinding and pelleting of the samples were repeated again and finally sintered at $1200{ }^{\circ} \mathrm{C}$ for 12 hours inside the furnace in air atmosphere with the same heating and cooling rate $\left(5^{\circ} \mathrm{C} / \mathrm{min}\right)$.

\subsection{Characterizations of the materials}

The D8 Advanced Bruker XRD system was used for X-ray diffraction experiments on the samples using with $\mathrm{CuK} \alpha_{1}$ radiation (wavelength, $\lambda=1.5406 \AA$ ) in angular range of $2 \theta=20^{\circ}$ to $80^{\circ}$ with a step size of $0.02^{\circ}$ at room temperature. For indexing the samples, the TREOR90 [52] and Checkcell [53] programs were used. For the Rietveld refinement of the XRD data, XRD were done for the angular range of $2 \theta=10^{\circ}$ to $90^{\circ}$ with step size of 0.01 and the FullProf [54] software was used for this refinement.

For microstructural studies, the powders were pressed into pellets by uniaxial press, sintered and investigated under the SEM instruments of JEOL 5600 and JSM-7610F. The Horiba Particle Size Distribution Analyzer LA-920 and Horiba Reservoir Unit LY-201 in wet mode were used to measure the size of the particles and their distribution in the materials.

The ionic conductivities of the samples were measured using a Solartron impedance and frequency response analyzer. For the measurements of EIS of the materials, the pellets of BCZYZ were well 
sintered and polished and then the surfaces of the pellets were made conducting by dispersed with platinum (Pt) ions in sputtering device of Quorom Q150RS before painting with Pt paste (as current collector) of about $5.2 \mathrm{~mm}$ in the central part of the surfaces on both sides of each pellet. The diameter of each pellet was around $13 \mathrm{~mm}$ and heated at $1000{ }^{\circ} \mathrm{C}$ for $40 \mathrm{~min}$ after the Pt painting. An amplitude of $50 \mathrm{~mA}$ was applied and the impedance were measured from 200 to $1000{ }^{\circ} \mathrm{C}$ with the interval of $50{ }^{\circ} \mathrm{C}$, with the heating rate of $3{ }^{\circ} \mathrm{C} / \mathrm{min}$ in $5 \% \mathrm{H}_{2}$ (with $95 \%$ Ar) at dry and wet atmospheres in the frequency range of $1 \mathrm{MHz}-10 \mathrm{mHz}$. The $5 \% \mathrm{H}_{2}$ gas was passed through two beds of $\mathrm{P}_{2} \mathrm{O}_{5}$ desiccant before entering the conductivity cell and is called the 'dry $\mathrm{H}_{2}$ '. The wet $\mathrm{H}_{2}$ atmosphere was prepared by flowing $5 \% \mathrm{H}_{2} / \mathrm{Ar}$ gas through water at room temperature $\left(22{ }^{\circ} \mathrm{C}\right)$. To ensure the equilibrium before spectra was recorded, sufficient time was allocated at each temperature for each atmosphere. The least squares refinement program Z-View (Scribner Associates Inc.) was used to fit the obtained impedance data. To represent the electrical response of the samples the brick-layer model was employed. Each arc from the experimental spectroscopy data was analyzed by a parallel arrangement of a resistance (R), an inductance (I) and a constantphase element (CPE). The resistance could not be removed reliably at temperature below $600^{\circ} \mathrm{C}$ due to high impedance. No correction for sample porosity was applied for the conductivity measurements.

Thermogravimetric analysis (TGA) was performed to study the chemical stability of the materials. The TGA data were collected for the powder samples in pure $\mathrm{CO}_{2}$ environment with a heating rate of $5{ }^{\circ} \mathrm{C} / \mathrm{min}$ from 30 to $1000{ }^{\circ} \mathrm{C}$. The samples were kept isothermally for $30 \mathrm{~min}$ at the final temperature and then cooled down to $50{ }^{\circ} \mathrm{C}$ at the same rate with the $\mathrm{CO}_{2}$ flow rate of $50 \mathrm{ml} / \mathrm{min}$ for both the carrier and protection. The XRD scans were done on the TGA samples to check any phase change after the TGA experiments. The thermal expansion coefficients of the materials were investigated by using temperature programmed SETARAM Instrumentation-SETSYS Evolution TMA S60 under the argon gas environment. 


\section{Results and discussion}

\subsection{The phase analysis}

Fig. 1 shows the Rietveld refinement of the room temperature XRD patterns of BCZYZ samples after sintered at $1200{ }^{\circ} \mathrm{C}$. The X-ray diffraction patterns confirm the single phase perovskite structure for all the four samples after Rietveld analysis and the peaks positions are matching with the BCZYZ in the literature [47].

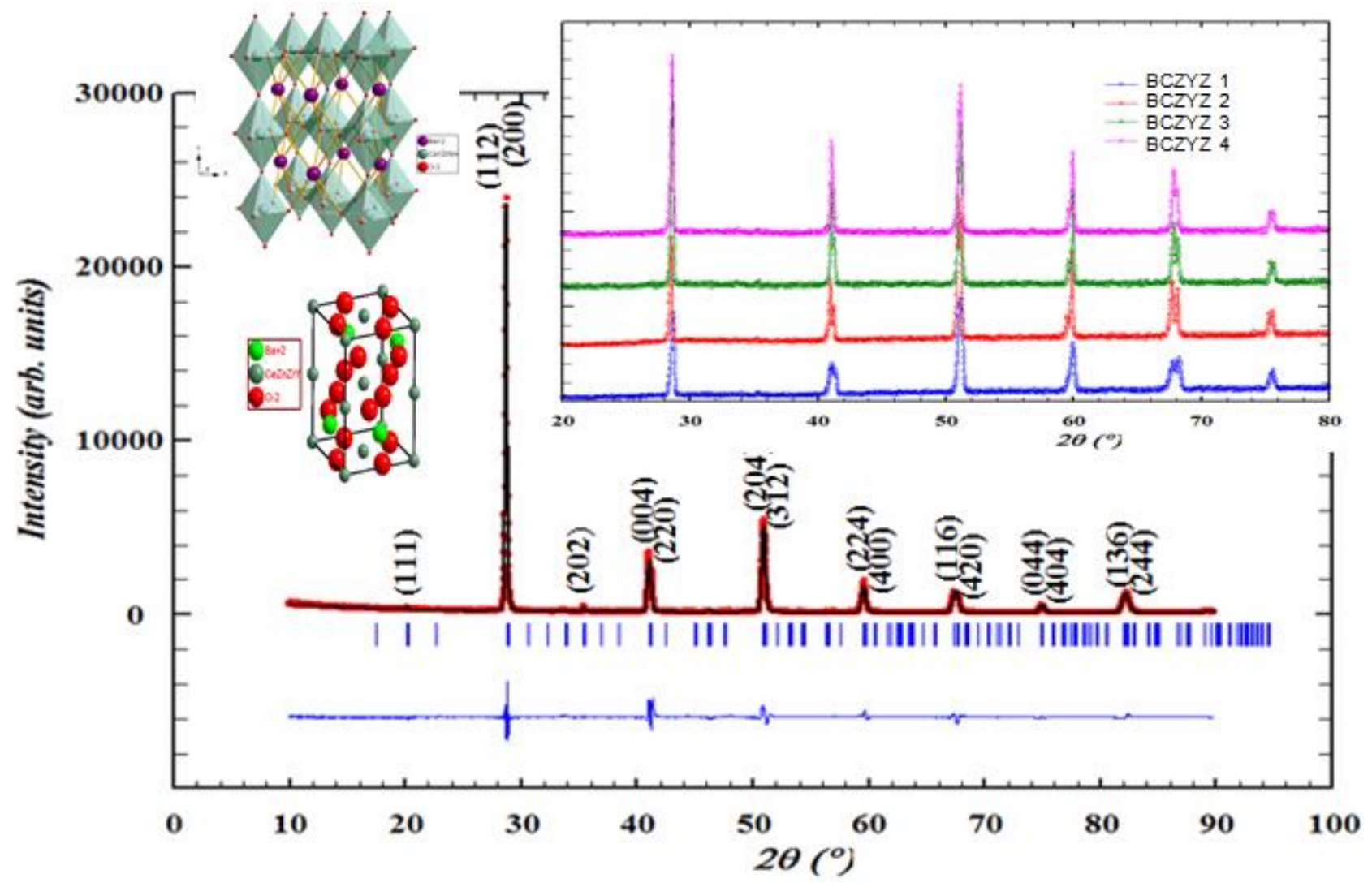

Fig. 1. Rietveld refinement patterns of $X R D$ data of as-prepared $\mathrm{BaCe}_{0.7} \mathrm{Zr}_{0.1} \mathrm{Y}_{0.1} \mathrm{Zn}_{0.1} \mathrm{O}_{3-\delta}(\mathrm{BCZYZ}$ 2) at room temperature. The XRD patterns for all the four samples are inserted in the top right and schematic 3D ball and stick diagram of BCZYZ 2 is inserted in the bottom left.

All samples exhibit the orthorhombic symmetry with the Pbnm space group. For creating the diffraction outlines in the data refinement process this space group has finally been used after vindicated with several additional crystals symmetries and space groups. 
In Table 1, the refinement parameters are listed. It is found in the Rietveld refinements results that the cell parameters of the crystal decrease with the increasing of zinc content which is due to the doping of smaller ionic radius of $\mathrm{Zn}$ (radius of $\mathrm{Zn}^{2+}=0.74 \AA$, coordination number $(\mathrm{CN})=6$ ) than yttrium (radius of $\mathrm{Y}^{3+}=0.90 \AA, \mathrm{CN}=6$ ).

Table 1. Cell parameters, atomic positions, oxygen occupancy, R-factors and densities of BCZYZ from the Rietveld analysis of the XRD data.

\begin{tabular}{|c|c|}
\hline Quantity & Results \\
\hline Unit cell parameters $(\AA)$ & $\begin{array}{l}\text { BCZYZ 1: } a=6.0981(9), b=6.102(7), c=8.666(3) \text { and } \alpha=\beta=\gamma=90^{\circ} \\
\text { BCZYZ 2: } a=5.9656(4), b=6.058(5), c=8.606(6) \text { and } \alpha=\beta=\gamma=90^{\circ} \\
\text { BCZYZ 3: } a=5.9018(7), b=5.992(9), c=8.547(4) \text { and } \alpha=\beta=\gamma=90^{\circ} \\
\text { BCZYZ 4: } a=5.8543(6), b=5.948(2), c=8.504(5) \text { and } \alpha=\beta=\gamma=90^{\circ}\end{array}$ \\
\hline Space group & Pbnm \\
\hline Atomic fractional & $\mathrm{Ba}(0.511,0.0120,0.250) ; \mathrm{Ce} / \mathrm{Zr} / \mathrm{Y} / \mathrm{Zn}(0,0,0) ; \mathrm{O} 1(0.155,0.156,0.250)$ and $\mathrm{O} 2$ \\
\hline coordinates (BCZYZ 2) & $(0.582,0.081,0.0004)$ \\
\hline Oxygen occupancy & $97-98 \%$ \\
\hline R-factors $(\%)$ & $\begin{array}{l}\text { BCZYZ 1: } \mathrm{R}_{\mathrm{p}}: 8.40, \mathrm{R}_{\mathrm{wp}}: 11.11, \mathrm{R}_{\mathrm{exp}}: 8.64, \chi^{2}: 2.45 \\
\text { BCZYZ 2: } \mathrm{R}_{\mathrm{p}}: 10.62, \mathrm{R}_{\mathrm{wp}}: 8.43, \mathrm{R}_{\mathrm{exp}}: 9.77, \chi^{2}: 2.33 \\
\text { BCZYZ 3: } \mathrm{R}_{\mathrm{p}}: 11.40, \mathrm{R}_{\mathrm{wp}}: 16.1, \mathrm{R}_{\mathrm{exp}}: 7.64, \chi^{2}: 4.45 \\
\text { BCZYZ 4: } \mathrm{R}_{\mathrm{p}}: 9.28, \mathrm{R}_{\mathrm{wp}}: 12.41, \mathrm{R}_{\mathrm{exp}}: 9.17, \chi^{2}: 2.03\end{array}$ \\
\hline Theoretical density $\left(\mathrm{g} / \mathrm{cm}^{3}\right)$ & $\mathrm{BCZYZ} 1=6.307, \mathrm{BCZYZ} 2=6.325, \mathrm{BCZYZ} 3=6.354, \mathrm{BCZYZ} 4=6.373$ \\
\hline Measured density $\left(\mathrm{g} / \mathrm{cm}^{3}\right)$ & $\mathrm{BCZYZ} 1=6.103, \mathrm{BCZYZ} 2=6.165, \mathrm{BCZYZ} 3=6.253, \mathrm{BCZYZ} 4=6.318$ \\
\hline Relative density $(\%)$ & $\mathrm{BCZYZ} 1=96.76, \mathrm{BCZYZ} 2=97.47, \mathrm{BCZYZ} 3=98.41, \mathrm{BCZYZ} 4=99.14$ \\
\hline
\end{tabular}

The theoretical densities from the Rietveld refinement of BCZYZ 1 - BCZYZ 4 were measured to be $6.307 \mathrm{~g} / \mathrm{cm}^{3}, 6.325 \mathrm{~g} / \mathrm{cm}^{3}, 6.354 \mathrm{~g} / \mathrm{cm}^{3}$ and $6.373 \mathrm{~g} / \mathrm{cm}^{3}$, respectively and the empirical density measured by the Archimedes' principle were $6.103 \mathrm{~g} / \mathrm{cm}^{3}, 6.165 \mathrm{~g} / \mathrm{cm}^{3}, 6.253 \mathrm{~g} / \mathrm{cm}^{3}$ and 6.318 $\mathrm{g} / \mathrm{cm}^{3}$, respectively. The percentage of relative density of BCZYZ samples were $96.76 \%$ to $99.14 \%$; 
and the relative density increased by increasing the $\mathrm{Zn}$ concentration. These relative densities are higher than that of the samples BCZYZ in the literature [47]. It was found that increasing in $\mathrm{Zn}$ content reduce the sintering temperature but increase the density of the materials.

\subsection{SEM analysis}

Fig. 2 (a) to (d) shows the SEM images of BCZYZ 1 to BCZYZ 4, respectively and the SEM morphologies of the reporting samples show highly dense features. No pores and cracks were found in the images which were sintered at $1200{ }^{\circ} \mathrm{C}$. The surface of the sample BCZYZ $2(\mathrm{x}=0.10)$ is very smoother and free of cracks. The samples are found highly dense which show non porous density features, and at all the investigated samples show very compact in natures which is one of the main requirements of electrolyte materials.
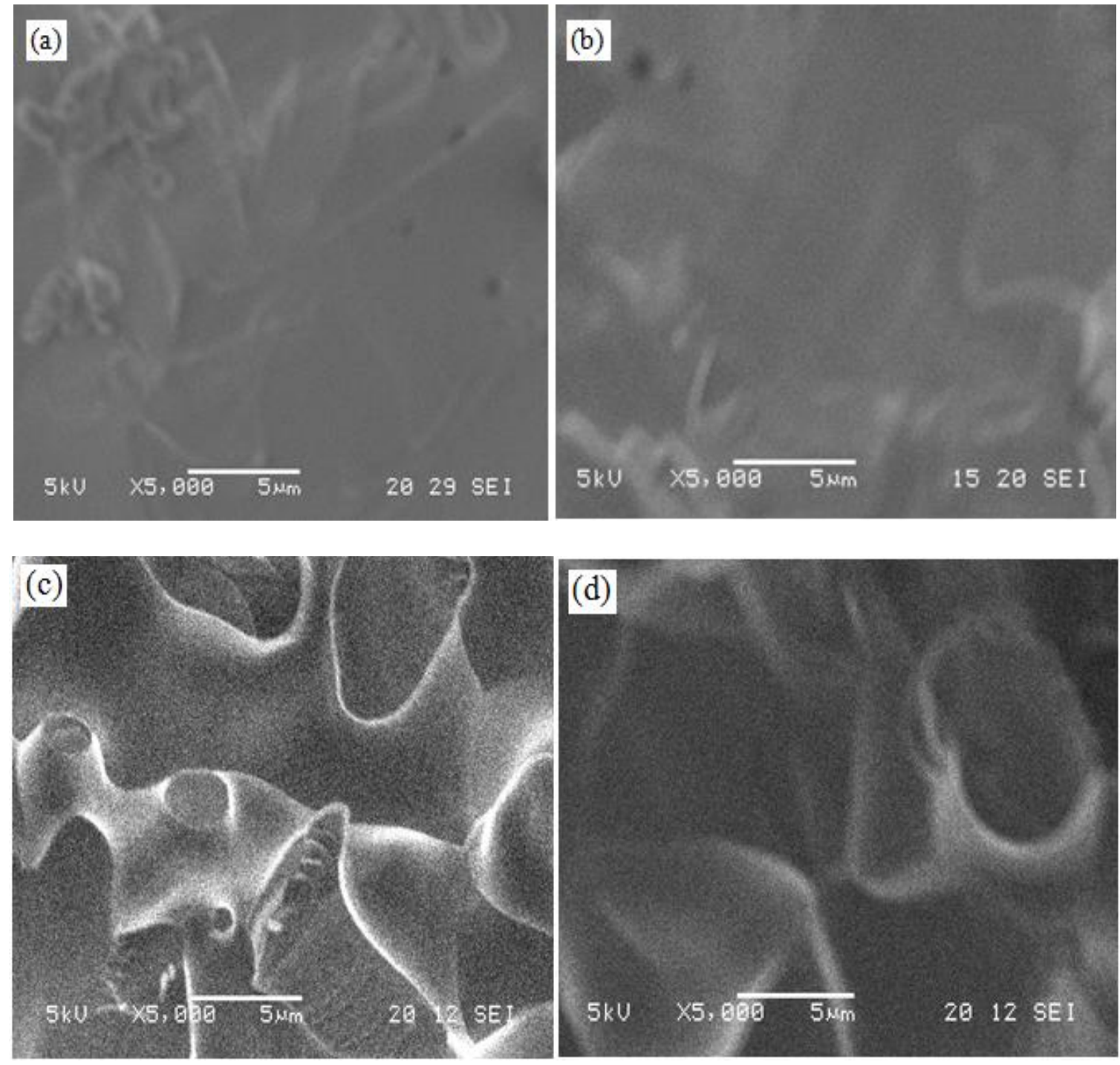
Fig. 2. SEM micrographs of as prepared (a) BCZYZ 1, (b) BCZYZ 2, (c) BCZYZ 3 and (d) BCZYZ 4; respectively.

As shown in images of 2 (a-d), it is observed that the reporting BCZYZ samples show the zinc replacement make the materials highly dense and the density of the materials increases with increasing the $\mathrm{Zn}$. In the SEM morphology, the bigger grain offers less overall grain boundary resistance and was found that $\mathrm{Zn}$ can be added to the structure by doping or can be used as sintering additives [43]. In this reporting composition, Zn has lower melting temperature $\left(419{ }^{\circ} \mathrm{C}\right)$ than $\mathrm{Ba}$ $\left(727{ }^{\circ} \mathrm{C}\right), \mathrm{Ce}\left(795{ }^{\circ} \mathrm{C}\right), \mathrm{Zr}\left(1855^{\circ} \mathrm{C}\right)$ and $\mathrm{Y}\left(1526{ }^{\circ} \mathrm{C}\right)$ which facilitates to decrease the sintering temperature of pure phase formation. For ionic conduction, the large grain size offers less grain boundary resistance that is quite good and Pergolesi et al. prepared grain boundary free materials too with high proton conduction [55]. It can be perceived that increasing the amount of zinc instead of yttrium leads to the rising the relative densities.

Li et al. showed the micrographs of the fracture surfaces of BCZYZ pellets after sintering at 1320 ${ }^{\circ} \mathrm{C}$ [56] which showed high density without obvious pores and cracks. In our study, we have observed similar density at $1200{ }^{\circ} \mathrm{C}$ without pores and cracks. The reported grain sizes of $\mathrm{BaZr}_{0.1} \mathrm{Ce}_{0.7} \mathrm{Y}_{0.1} \mathrm{M}_{0.1} \mathrm{O}_{3-\delta}(\mathrm{M}=\mathrm{Fe}, \mathrm{Ni}, \mathrm{Co}$ and $\mathrm{Yb})$ were quite good but were sintered at $1250{ }^{\circ} \mathrm{C}$ for $24 \mathrm{~h}, 1350{ }^{\circ} \mathrm{C}$ for $24 \mathrm{~h}$ and $1550{ }^{\circ} \mathrm{C}$ for $12 \mathrm{~h}$, respectively, [57]; are higher than our sintering temperature $\left(1200{ }^{\circ} \mathrm{C}\right)$. Bi et al. showed the grain sizes of $2-8 \mu \mathrm{m}$ for $\mathrm{BaCe}_{0.5} \mathrm{Zr}_{0.3} \mathrm{Y}_{0.2} \mathrm{O}_{3-\delta}$ which was sintered at $1600{ }^{\circ} \mathrm{C}$ for $8 \mathrm{~h}$ [58]. The observed grain sizes for BZCY and BZCYYb $(5 \mu \mathrm{m}$ and 3 $\mu \mathrm{m}$ after heating at $1400{ }^{\circ} \mathrm{C}$ for $6 \mathrm{~h}$, respectively) [32], [59], [60], of $\mathrm{BaZr}_{0.7} \operatorname{Pr}_{0.1} \mathrm{Y}_{0.2} \mathrm{O}_{3-\delta}(\mathrm{BZPY})$ (reported $1.7 \mu \mathrm{m}$, sintered at $1600{ }^{\circ} \mathrm{C}$ for $8 \mathrm{~h}$ ), BZCYYb $\left(1.0 \mu \mathrm{m}\right.$, sintered at $1400{ }^{\circ} \mathrm{C}$ for $5 \mathrm{~h}$ ) [60], [61] or, BCZYZ (about $1 \mu \mathrm{m}$, sintered at $1400^{\circ} \mathrm{C}$ for $22 \mathrm{~h}$ ) [47] were very good too; but the sintering temperatures were higher than our reporting temperature. It is found in our reporting 
compositions that the doping of zinc is helpful not only for good densification but also for lowering the sintering temperature.

Table 2 shows the elemental distribution from energy dispersive X-ray analysis (EDX) of BCZYZ materials which are very close to the calculated value from the chemical formula $(\% \mathrm{~F})$.

Table 2. Elemental distribution of BCZYZ 1 and BCZYZ 3 by formula and EDX analysis.

\begin{tabular}{|c|c|c|c|c|c|c|c|c|}
\hline \multirow{3}{*}{$\begin{array}{l}\text { Sample } \\
\text { Element }\end{array}$} & \multicolumn{4}{|c|}{ BCZYZ 1} & \multicolumn{4}{|c|}{ BCZYZ 3} \\
\hline & \multicolumn{2}{|c|}{ Formula } & \multicolumn{2}{|c|}{ EDX } & \multicolumn{2}{|c|}{ Formula } & \multicolumn{2}{|c|}{ EDX } \\
\hline & Weight & Atomic & Weight & Atomic & Weight & Atomic & Weight $\%$ & Atomic \\
\hline Symbol & $\%$ & $\%$ & $\%$ & $\%$ & $\%$ & $\%$ & & $\%$ \\
\hline $\mathrm{Ba}$ & 52.59 & 50.0 & 51.95 & 49.68 & 53.07 & 50.0 & 52.87 & 50.12 \\
\hline $\mathrm{Ce}$ & 37.56 & 35.0 & 37.85 & 35.14 & 37.90 & 35.0 & 37.96 & 34.76 \\
\hline $\mathrm{Zr}$ & 3.49 & 5.0 & 3.63 & 5.09 & 3.53 & 5.0 & 3.59 & 5.07 \\
\hline Y & 5.11 & 7.5 & 5.19 & 7.56 & 1.72 & 2.5 & 1.67 & 2.52 \\
\hline $\mathrm{Zn}$ & 1.25 & 2.5 & 1.38 & 2.53 & 3.79 & 7.5 & 3.91 & 7.53 \\
\hline
\end{tabular}

It is observed from the EDX analysis that the reporting BCZYZ materials have close ratio of elements to the calculated values with the chemical formula; i.e., the elemental distribution of BCZYZ by formula and EDX analysis show the same values (both in weight and atomic compositions). Any impurity phase (unreacted materials of ingredients chemicals) was not observed from EDX studies or it must be below the detection limit of our instrument. As no extra phase were found in EDX analysis, it can be mentioned that there are no unreacted particles in the materials after solid state reaction sintered at $1200{ }^{\circ} \mathrm{C}$ which was confirmed from the Rietveld refinement of the XRD data (section 3.1, the phase analysis).

\subsection{Distribution of particle size}


The particle size distribution of BCZYZ was investigated in powder form after final sintering at $1200{ }^{\circ} \mathrm{C}$. To obtain proper distribution of particles each composition of the powders were sonicated for $3 \mathrm{~h}$ at $70{ }^{\circ} \mathrm{C}$.

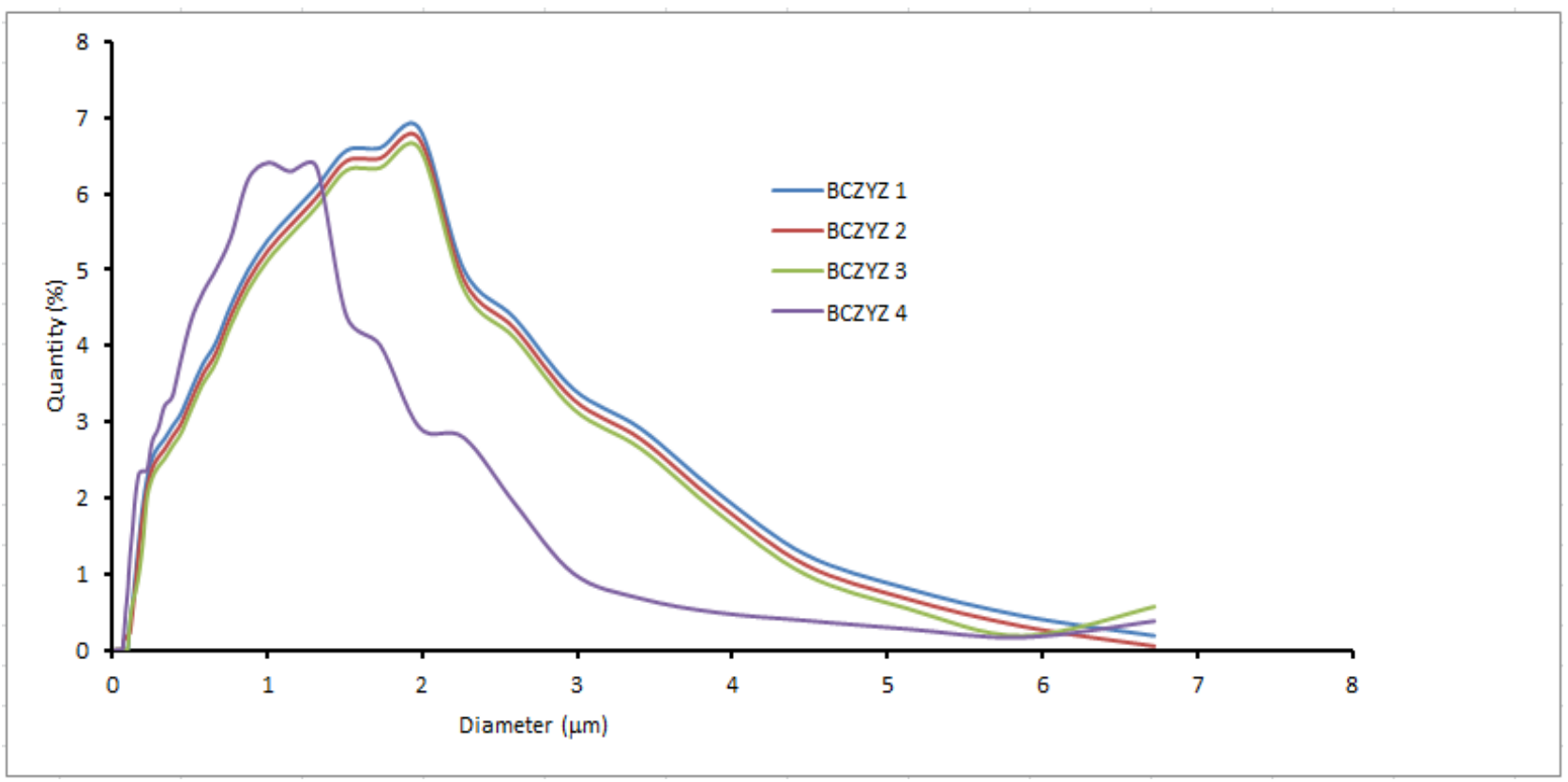

Fig. 3. The particle size distribution on quantity and diameter of the BCZYZ samples over the metal oxides.

In Fig. 3 it is found that the sizes of the particles decrease with $\mathrm{Zn}$ concentration indicating that the particle size of the material depends on the diameter of the particle as well as unit cell volume. The diameter range of BCZYZ particles remain within $0 \sim 2.3 \mu \mathrm{m}$. The metallic oxide particles addition not only raises the diffusion of water into the growing material due to its advanced hydrophilic property but also affects the interaction between the material particles and solvent molecules by the hindrance effect of the particles.

\subsection{Electrochemical impedance spectroscopy (EIS)}

Figures 4 (a) to (d) shows the EIS studies of the materials BCZYZ 3 and BCZYZ 4 in the temperature range $600-1000{ }^{\circ} \mathrm{C}$ in $5 \% \mathrm{H}_{2}$ with $\mathrm{Ar}$ in dry and wet atmospheres, respectively. The 
equivalent circuits of the fitted impedance data were attained for BCZYZ oxides within the temperature range of $600{ }^{\circ} \mathrm{C}$ to $1000{ }^{\circ} \mathrm{C}$ and are inserted in the figures. The impedance curves of the BCZYZ materials are analyzed by the form of two or one semicircle and those semicircles indicate the polarization resistance of the materials as grain boundaries for all the recorded temperature range of $200-1000{ }^{\circ} \mathrm{C}$ in $5 \% \mathrm{H}_{2} / \mathrm{Ar}$ at dry and wet conditions. The range of $10^{-2}-10^{-3} \mathrm{~S}$ $\mathrm{cm}^{-1}$ at $600{ }^{\circ} \mathrm{C}$ temperature, an ionic conductivity is considered suitable for practical applications of proton conducting oxides. In order to disseminate between different responses (grain/grain boundary), ac impedance technique was employed to measure the ionic conductivities of BCZYZ in dry and wet $\mathrm{H}_{2}$ atmospheres, respectively.
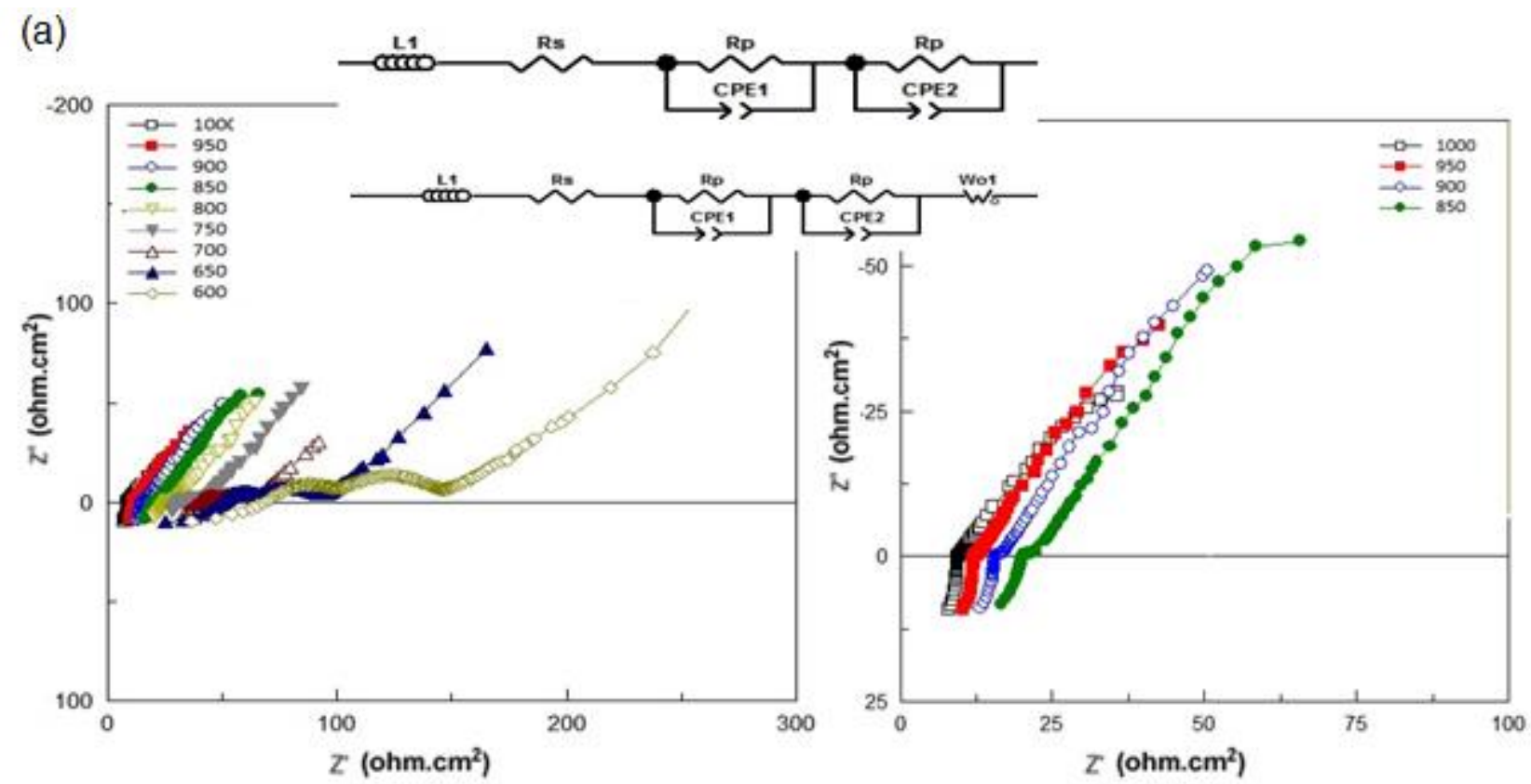
(b)
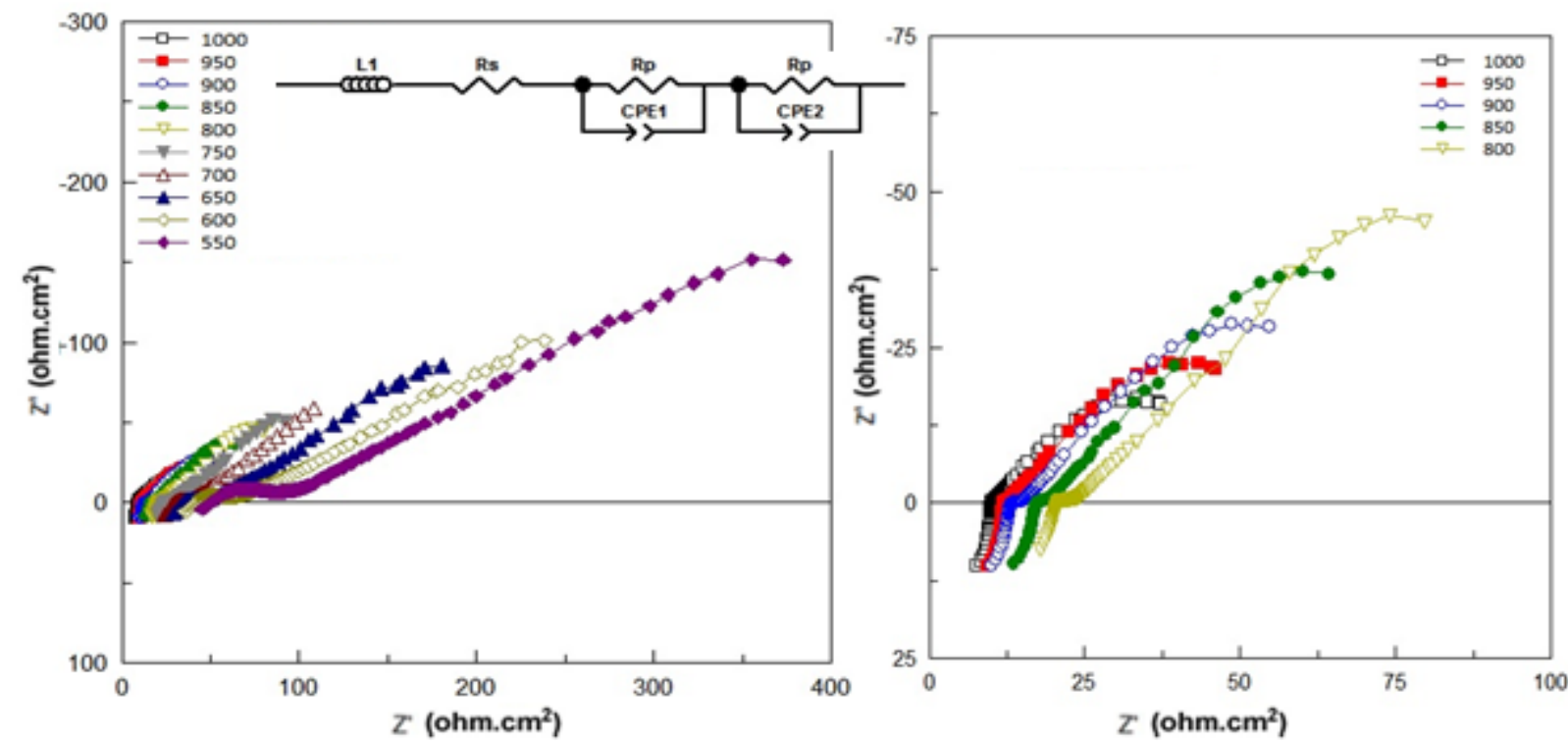

(c)
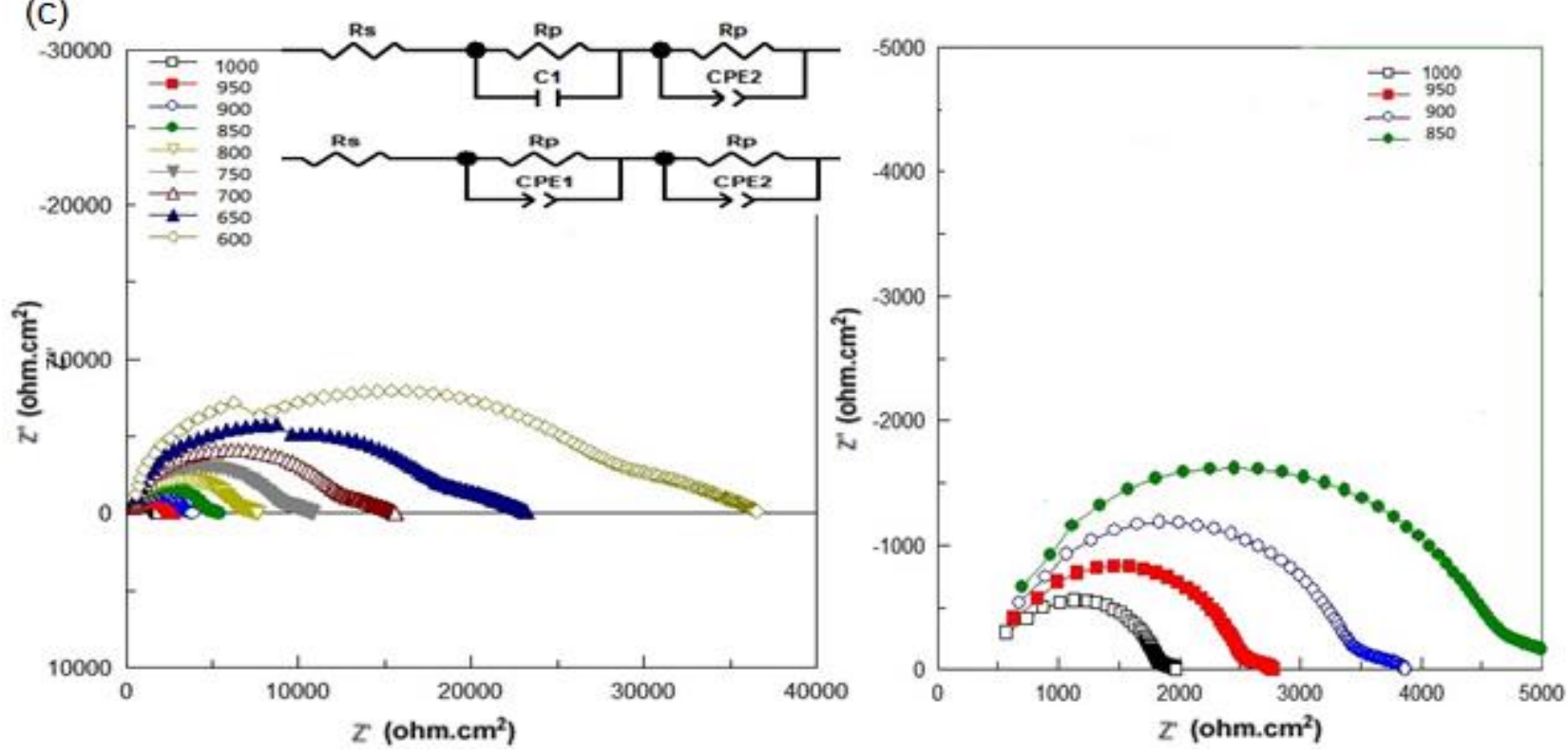
(d)

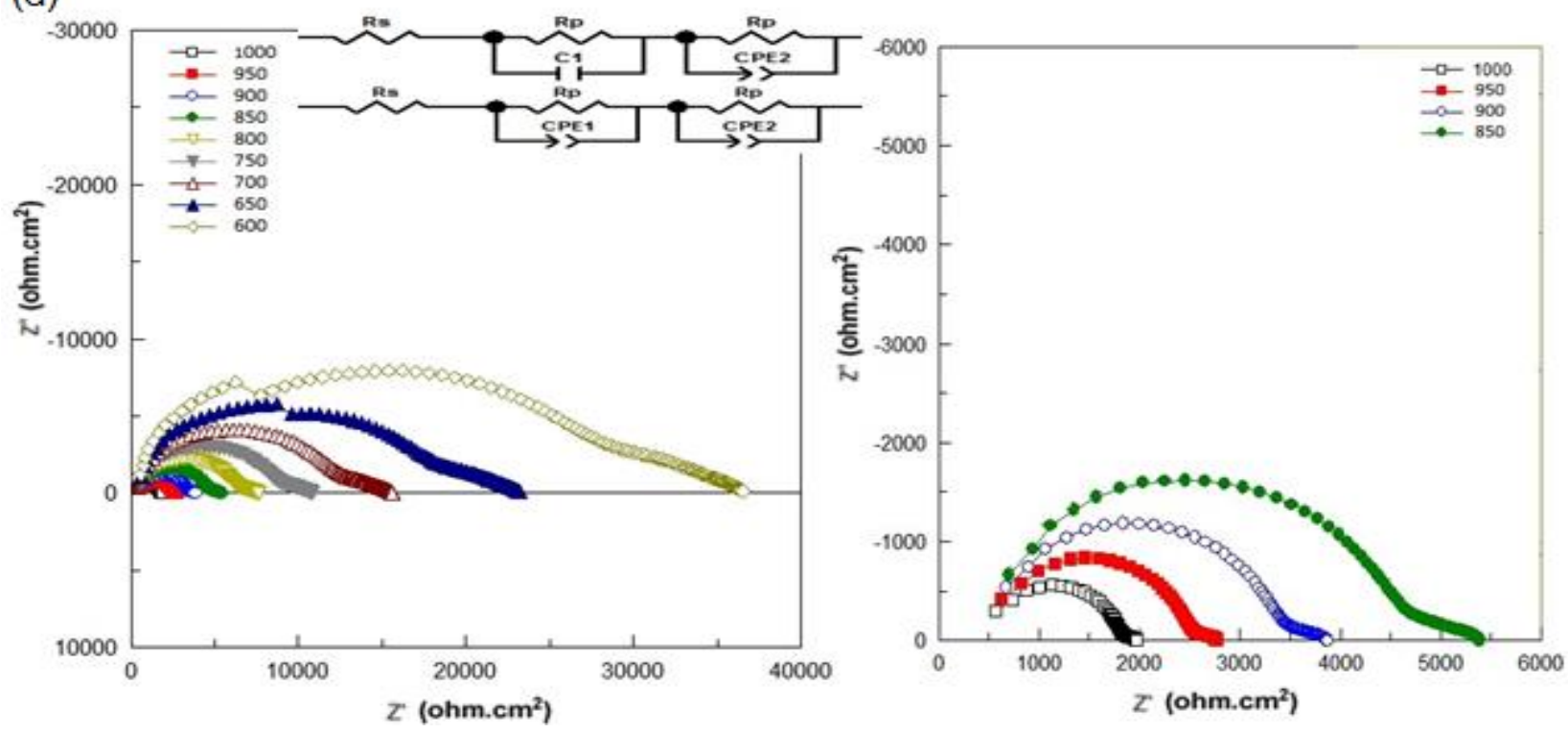

Fig. 4. Nyquist plots of (a-b) BCZYZ 3 and (c-d) BCZYZ 4, in 5\% $\mathrm{H}_{2}$ with Ar in dry and wet atmospheres, respectively at $600^{\circ} \mathrm{C}$ to $1000^{\circ} \mathrm{C}$ temperatures; right hand side figures are the magnified views for the specific temperatures. The respective equivalent circuits are shown in the insert in the figures.

The Nyquist plots of BCZYZ 3 and BCZYZ 4 is dry and wet $5 \% \mathrm{H}_{2}$ show different patterns especially in the low frequency region. In case of BCZYZ 3, we observed Warburg impedance which is a straight line with a slope of $45^{\circ}$ at lower frequencies. Warburg impedance arises from the mass-transfer diffusion process. The most significant compositional difference between BCZYZ 3 and $\mathrm{BCZYZ} 4$ is yttrium $(\mathrm{Y})$; in $\mathrm{BCZYZ} 3$ there is $15 \% \mathrm{Zn}(\mathrm{x}=0.15)$ at the $\mathrm{B}$-site of the perovskite structure whereas in BCZYZ 4 there is $20 \% \mathrm{Zn}(\mathrm{x}=0.20)$, but not any yttrium. The surface and elemental properties of these two compositions are different which makes different types of diffusion mechanism.

The Arrhenius plots of total conductivity for all the four samples are shown in Fig. 5 (a-b) under $5 \% \mathrm{H}_{2}$ in dry and wet atmospheres, respectively. The EIS measurements of BCZYZ were done at 200-1000 ${ }^{\circ} \mathrm{C}$ at an interval of $50{ }^{\circ} \mathrm{C}$. The conductivity of any material can be observed by impedance which is equivalent to resistivity i.e., for the electrolyte material small impedance value 
is preferred to achieve high conductivity. Due to high impedance of our studied materials of BCZYZ at low temperature, e.g. $\mathrm{T} \leq 600{ }^{\circ} \mathrm{C}$ the resistance could not be extracted reliably; therefore, only total conductivity at the temperature of $600{ }^{\circ} \mathrm{C}$ and higher were calculated and displayed in the Fig. 5. It was problematic to separate the bulk from the grain boundary conductivities below the temperature of $600{ }^{\circ} \mathrm{C}$, although typically $3 \mathrm{RC}$ (resistance in combination with parallel to CPE) equivalent circuits in series (shown in Fig. 4 insert) is used, especially in temperature region below $200{ }^{\circ} \mathrm{C}$ an additional $\mathrm{RC}$ element gives better fit for the complex electrode responses. We have also perceived a significant better fit with addition of inductance, especially in higher temperature ranges (above $600{ }^{\circ} \mathrm{C}$ ) contributions. For BCZYZ samples the total conductivities rise with the rise of temperature mutually in dry and wet conditions. The valence state of $\mathrm{Zn}$ is +2 . Doping with cations with valence state +4 and +3 , we can make more oxygen vacancies. In oxide proton conductors, oxygen vacancies play an important role to enhance conductivity. For the compositions of BCZYZ we also found high conductivity even with dry $\mathrm{H}_{2}$ because of proton conduction. In proton conductors, ionic conductivity is done by proton $\left(\mathrm{H}^{+}\right)$. So, even for the dry $\mathrm{H}_{2}$ protonic conductivity is good.

The conductivities in wet condition are greater than dry condition which confirms the proton conductivity in the sample at the intermediate temperature $\left(600-700{ }^{\circ} \mathrm{C}\right)$. At the temperatures above $800{ }^{\circ} \mathrm{C}$ (higher temperature), the conductivities are higher which may be due to the oxygen plus protonic effect which are not the requirement of intermediate temperature electrolyte materials. In wet hydrogen atmospheres the total conductivities of BCZYZ 2 are about $8.6 \times 10^{-3} \mathrm{~S} \mathrm{~cm}^{-1}$ and 1.0 $\times 10^{-2} \mathrm{~S} \mathrm{~cm}^{-1}$ at $600{ }^{\circ} \mathrm{C}$ and $700{ }^{\circ} \mathrm{C}$, respectively which are very good values in comparison to other studied proton conductors until now. The conductivities at intermediate temperature of 600 to 700 ${ }^{\circ} \mathrm{C}$, for samples BCZYZ 1, BCZYZ 3 and BCZYZ 4 are also higher and the minimum value found to be $3.84 \times 10^{-3}$ for BCZYZ 4 in the dry and wet $\mathrm{H}_{2}$ atmospheres. It is seen from the EIS curves that BCZYZ 1 to BCZYZ 3 show different impedance patterns in dry $\mathrm{H}_{2}$ and wet $\mathrm{H}_{2}$ atmospheres, 
but not for the BCZYZ 4. This is due to the optimum doping percentage of $\mathrm{Zn}$ (the optimum doping of $\mathrm{Zn}$ is around $10 \mathrm{wt} \%$ ) in $\mathrm{BaCeO}_{3}-\mathrm{BaZrO}_{3}$ based materials.

In Fig. 5 (a) and (b), the Arrhenius plots of the total ionic conductivity of the materials are shown in dry and wet hydrogen atmospheres in the temperature range of $600-1000{ }^{\circ} \mathrm{C}$. It is found that with the increasing temperature cause thermally vibrated particles or the atoms and passage the ions easily as the conductivity increases. About $3 \%$ of water molecule flow with $\mathrm{H}_{2}$ in wet hydrogen atmosphere that enhance the conductivity by ion transport mechanism. This atmosphere increases the conductivity compared to dry atmosphere.

(a)

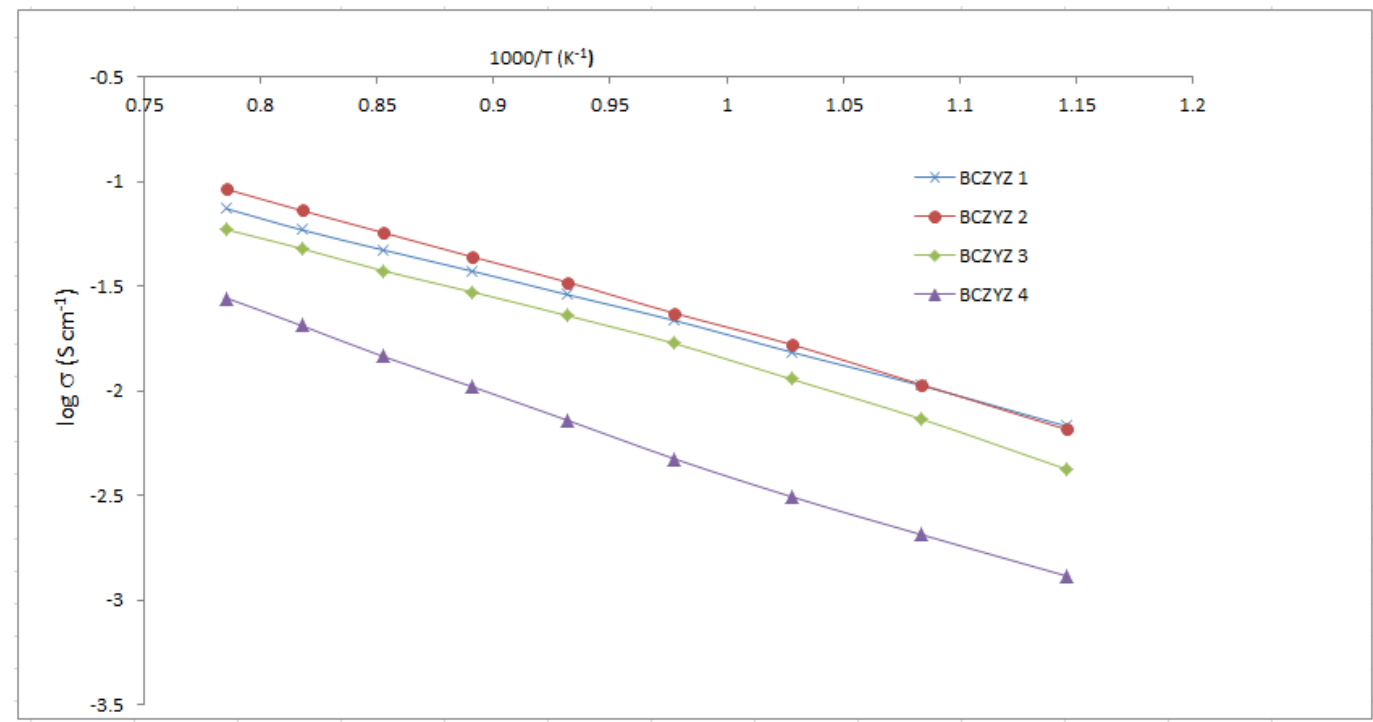

(b)

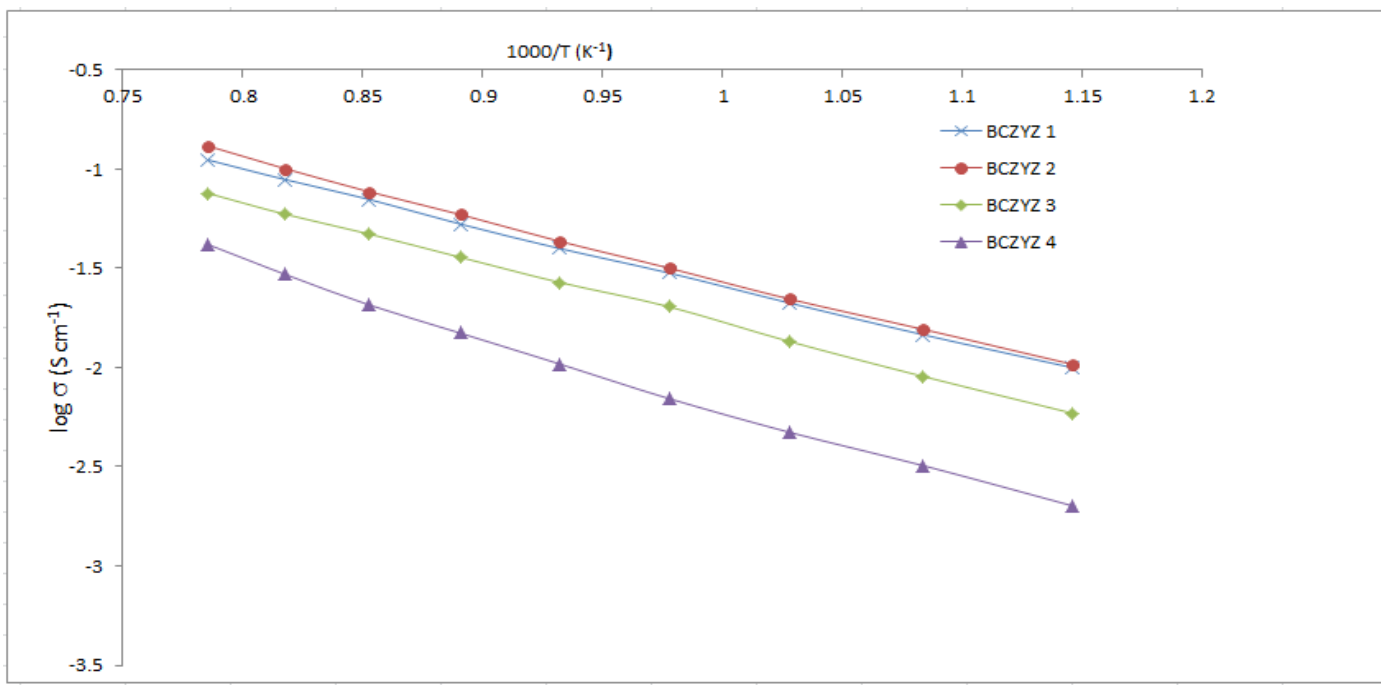


Fig. 5. Arrhenius plots of the total conductivity measured in $5 \% \mathrm{H}_{2} / \mathrm{Ar}$ (a) dry and (b) wet atmospheres, in the temperature range of $600{ }^{\circ} \mathrm{C}-1000^{\circ} \mathrm{C}$.

Table 3 shows the conductivity and activation energy for the compositions of BCZYZ. As in 5\% wet $\mathrm{H}_{2}$ the conductivity is higher than that of dry, activation energy of $5 \%$ wet $\mathrm{H}_{2}$ material is lesser than that of dry $\mathrm{H}_{2}$ owing to the atoms in composites accomplish their ability to conduct ion demanding fewer activation energy to support. The activation energy of these BCZYZ are lower than $\mathrm{BaCe}_{0.8} \mathrm{Y}_{0.2} \mathrm{O}_{3-\delta}(\mathrm{AE}=0.39 \mathrm{eV})$ and $\mathrm{BaZr}_{0.8} \mathrm{Y}_{0.2} \mathrm{O}_{3-\delta}(\mathrm{AE}=0.61 \mathrm{eV})$ [19].

Table 3. List of conductivity and activation energy of BCZYZ under dry and wet $\mathrm{H}_{2}$ environment.

\begin{tabular}{c|cccc|cc}
\hline \multirow{2}{*}{ Material } & \multicolumn{3}{|c|}{ Conductivity $\left(\mathrm{S} \mathrm{cm}^{-1}\right)$} & \multicolumn{2}{c}{ Activation energy (eV) } \\
\cline { 2 - 7 } Composition & \multicolumn{2}{|c}{$600{ }^{\circ} \mathrm{C}$} & \multicolumn{2}{c}{$70{ }^{\circ} \mathrm{C}$} & $60{ }^{\circ} \mathrm{C}$ & $700{ }^{\circ} \mathrm{C}$ \\
& Dry $\mathrm{H}_{2}$ & Wet $5 \% \mathrm{H}_{2}$ & Dry $\mathrm{H}_{2}$ & Wet $5 \% \mathrm{H}_{2}$ & Dry $\mathrm{H}_{2}$ & Wet 5\% $\mathrm{H}_{2}$ \\
\hline BCZYZ 1 & $6.72 \times 10^{-3}$ & $8.55 \times 10^{-3}$ & $7.55 \times 10^{-3}$ & $9.58 \times 10^{-3}$ & 0.3867 & 0.3346 \\
BCZYZ 2 & $6.67 \times 10^{-3}$ & $8.59 \times 10^{-3}$ & $7.73 \times 10^{-3}$ & $9.97 \times 10^{-3}$ & 0.3849 & 0.3311 \\
BCZYZ 3 & $4.03 \times 10^{-3}$ & $5.69 \times 10^{-3}$ & $5.65 \times 10^{-3}$ & $6.18 \times 10^{-3}$ & 0.4136 & 0.3427 \\
BCZYZ 4 & $3.84 \times 10^{-3}$ & $4.24 \times 10^{-3}$ & $4.14 \times 10^{-3}$ & $4.77 \times 10^{-3}$ & 0.4324 & 0.3948 \\
\hline
\end{tabular}

The protons in proton conducting perovskites, at elevated temperatures are hypothetically follow the Grotthuss mechanism [62] and passage in the subsequent steps: i) a proton in connections with a permanent oxygen atom; ii) under the effect of the adjacent oxygen atoms the proton oxygen bond reorients; and finally iii) the proton starts to vibrate among the two oxygen atoms and ultimately migrates to the adjacent oxygen [63], [64]. The binding energy among $\mathrm{OH}^{\circ}$ and $\mathrm{M}_{\mathrm{B}^{\prime}}$ fluctuates with the dopant. Results show from the simulation that the binding energies of $\mathrm{OH}^{\circ}-$ $\mathrm{M}_{\mathrm{B}^{\prime}}$ (hydroxyl - dopant pairs at the adjacent sites) for $\mathrm{Y}, \mathrm{Yb}$ and In were $-0.26,-0.35$ and $-0.58 \mathrm{eV}$, 
respectively which has worthy settlement with the experimental effects [65]. A higher negative value of the binding energies will be observed for a further stable state of hydroxyl - dopant pair.

The conductivity is higher in wet $\mathrm{H}_{2}$ than in dry indicating proton conduction. In general, the wellsintered samples of BCZYZ exhibit much higher conductivity than the less dense materials under the same conditions. The conductivity of the $\mathrm{BaZrO}_{3}$ based proton conductor stalwartly depends upon materials synthesis and the determining environments. High total conductivity is preferred for the electrolyte of any real electrochemical cell. From this point of view, BCZYZ 2 displays the utmost total proton conductivity amongst the materials studied here.

The conductivity of the well-sintered sample BCZYZ is much higher and at low temperature, the conduction of proton is limited by the grain boundary rather than the bulk. At high temperature in the presence of steam, both the bulk and grain boundary conductivities are enhanced. The at high temperature grain boundary resistance is insignificant for the well-sintered sample. The total conductivity of $\mathrm{BCZYZ}$ reaches much higher than $1.0 \times 10^{-3} \mathrm{~S} \mathrm{~cm}^{-1}$ at and above $600{ }^{\circ} \mathrm{C}$. According to our results listed in Table 3, the conductivities in wet $5 \% \mathrm{H}_{2}$ is higher than dry $5 \% \mathrm{H}_{2}$ at 600 and $700{ }^{\circ} \mathrm{C}$ for all samples. Dry $\mathrm{H}_{2}$ is not $100 \%$ dried and $\mathrm{H}_{2}$ itself can convert to proton to conduct. In every literatures measuring conductivity in dry $\mathrm{H}_{2}$ or Ar have some conductivity but less than wet condition [15]. The optimum highest temperature for protonic conduction is $700{ }^{\circ} \mathrm{C}$. There can be some protonic conduction at $1000{ }^{\circ} \mathrm{C}$ which must be negligible.

After the conductivity analysis it can be observed that $\mathrm{Zn}$ doping is very significant for densification and lowering the sintering temperature, as well as grain growth but it is very important to know the optimum doping percentage. From this study we have found that the optimum doping is $10 \mathrm{wt} \%$; after this range for our reporting compositions the grain size and densification become higher but conductivity becomes lesser.

\subsection{Thermomechanical analysis}


The thermomechanical properties of $\mathrm{BaCe}_{0.7} \mathrm{Zr}_{0.1} \mathrm{Y}_{0.2-\mathrm{x}} \mathrm{Zn}_{\mathrm{x}} \mathrm{O}_{3-\delta}(\mathrm{x}=0.05,0.10,0.15$ and 0.20$)$ is shown in Fig. 6 and is found that the composition with $\mathrm{x}=0.20$ has the lowest thermal expansion compared to other samples. Fig. 6 reveals that the thermal expansion coefficient (TEC) decreased with the increase of zinc content but increase with the temperature. Inversely, decreasing of yttrium content in BCZYZ also show the decrease in TEC.

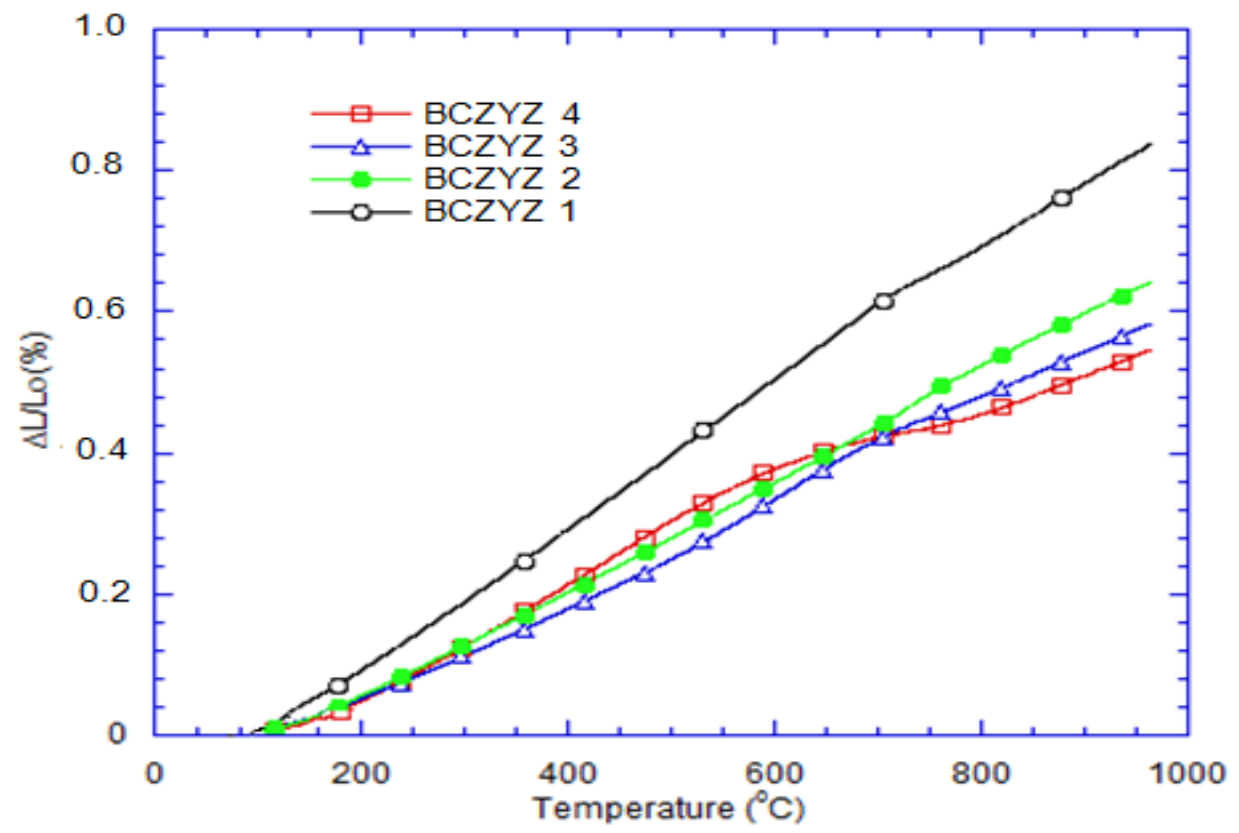

Fig. 6. Thermal expansion curve of $\mathrm{BaCe}_{0.7} \mathrm{Zr}_{0.1} \mathrm{Y}_{0.2-\mathrm{x}} \mathrm{Zn}_{\mathrm{x}} \mathrm{O}_{3-\delta}(\mathrm{x}=0.05,0.10,0.15$ and 0.20$)$.

The thermomechanical properties were studied on all compositions of BCZYZ in argon environment. The results show the TECs values of $9.23 \times 10^{-6} /{ }^{\circ} \mathrm{C}, 8.81 \times 10^{-6} /{ }^{\circ} \mathrm{C}, 8.74 \times 10^{-6} /{ }^{\circ} \mathrm{C}$ and $8.68 \times 10^{-6} /{ }^{\circ} \mathrm{C}$, respectively for $\mathrm{x}=0.05,0.10,0.15$ and 0.20 , respectively at $700{ }^{\circ} \mathrm{C}$. Above $700{ }^{\circ} \mathrm{C}$, the rate of variation of TEC is different due to the crossing the range of proton conduction. The conduction mechanism can differ from proton to oxide ion which might be related to the small change in thermal expansion at high temperature $\left(>750{ }^{\circ} \mathrm{C}\right)$.

\subsection{Chemical stability}

The cerium based proton conducting electrolyte materials have some challenges in its stability in $\mathrm{CO}_{2}$ containing atmosphere [66] because of $\mathrm{BaCeO}_{3}$ reacts with $\mathrm{CO}_{2}$ and forms $\mathrm{BaCO}_{3}$ and $\mathrm{CeO}_{2}$. 
At $1141{ }^{\circ} \mathrm{C}$, this chemical reaction has been reported to occur [11], but our interests for the reporting materials to be applied in intermediate temperature, i.e., below the temperature of 1000 ${ }^{\circ} \mathrm{C}$, so all the samples of $\mathrm{BCZYZ}$ for comparison were heated up to $1000{ }^{\circ} \mathrm{C}$ in pure $\mathrm{CO}_{2}$ at 5 ${ }^{\circ} \mathrm{C} / \mathrm{min}$ from 30 to $1000{ }^{\circ} \mathrm{C}$, held isothermally for $30 \mathrm{~min}$, and then cooled down to $50{ }^{\circ} \mathrm{C}$ at the same rate, with the flow rate of $50 \mathrm{ml} / \mathrm{min}$ for both the carrier and protection gas. The heat treatment in $\mathrm{CO}_{2}$ up $1200{ }^{\circ} \mathrm{C}$ or a bit higher has already been reported by numerous researchers in the literatures [67], [68].

Fig. 7 (a) shows the thermogravimetric analysis (TGA) curves for BCZYZ samples. The TGA experiment were done for measuring the sample chemical stability and, it was seen that the mass of BCZYZ 1 to BCZYZ 4 changed by $0.59 \%, 1.08 \%, 1.21 \%$ and $2.19 \%$, respectively. Before the XRD we have put the TGA samples in $\mathrm{CO}_{2}$ atmosphere for duration of 10 days.

The samples of higher $\mathrm{Zn}$ content (BCZYZ 4) was found relatively more stable than the less $\mathrm{Zn}$ content and no peaks were observed in XRD in any of the sample after the TGA experiments (as shown in Fig. 7 (b)) i.e., the original structures were unaffected by the experiment in $\mathrm{CO}_{2}$ atmosphere. 
(a)

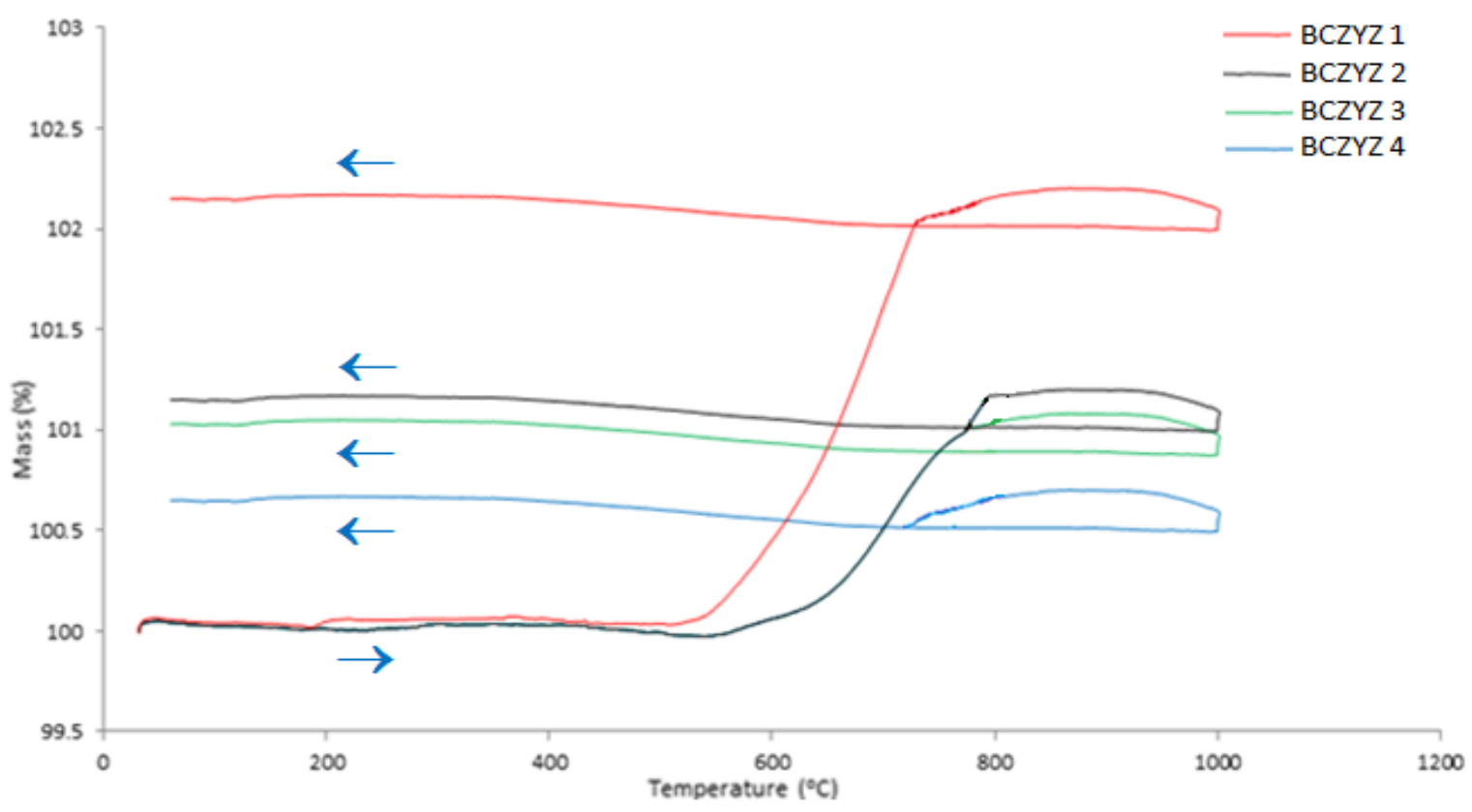

(b)

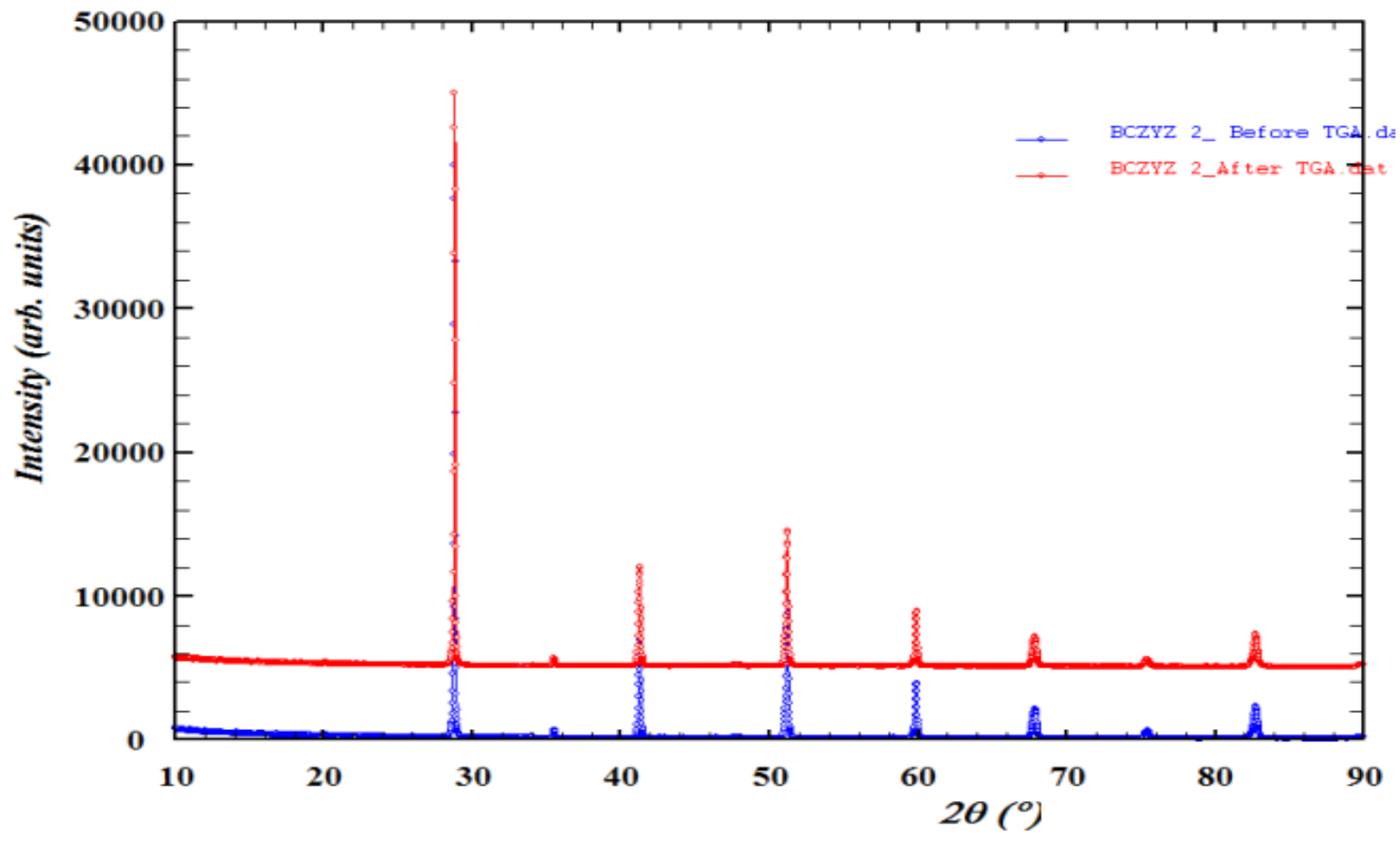

Fig. 7. (a) TGA curves for BCZYZ (names of the samples are inserted to the top right) with the flowing of pure $\mathrm{CO}_{2}$ gas at a rate of $50 \mathrm{ml} / \mathrm{min}$ for both the carrier and protection; (b) the XRD patterns of BCZYZ 2 before and after the TGA experiment. No extra or impurity peaks were observed after the TGA. 
There is a small weight gain of $\leq 0.6 \%$ after stability test as can be seen from curve of Fig. 7 (a) for the sample BCZYZ 4 which is much smaller than weight gain of $1.79 \%$ for BZ3C5YYb and $2.19 \%$ for the sample of BCZYZ 1 which is also smaller than that of BZ3C5YYb. The weight gain of BCZYZ $4(0.59 \%)$ in comparison to the weight gain for a composition with higher $\mathrm{Zr}$ content of 70 mol\% at the $\mathrm{B}$ site i.e., $\mathrm{BaCe}_{0.2} \mathrm{Zr}_{0.7} \mathrm{Y}_{0.1} \mathrm{O}_{3-\delta}$, which was about $0.3-0.4 \%$, when heated up to 1250 ${ }^{\circ} \mathrm{C}$ with a heating/cooling rate of $2{ }^{\circ} \mathrm{C} / \mathrm{min}$ in pure $\mathrm{CO}_{2}$ [69]. For composition with $30 \mathrm{~mol} \%$ of $\mathrm{Zr}$ at the $\mathrm{B}$ site i.e., $\mathrm{BaC}_{0.6} \mathrm{Zr}_{0.3} \mathrm{Y}_{0.1} \mathrm{O}_{3-\delta}$, the increase in weight was about $2 \%$ under the same atmospheres up to $1250{ }^{\circ} \mathrm{C}$ in pure $\mathrm{CO}_{2}$ as for $70 \mathrm{~mol} \%$ of zirconia. In case of $\mathrm{BZCYYb}$, when heated to $1200{ }^{\circ} \mathrm{C}$ in pure $\mathrm{CO}_{2}$ with a heating/cooling rate of $10{ }^{\circ} \mathrm{C} / \mathrm{min}$, the increase in weight was 7.7\%. Similarly, for the material of $\mathrm{BaCe}_{0.5} \mathrm{Zr}_{0.3} \mathrm{Y}_{0.2} \mathrm{O}_{3-\delta}$, when heated up to $1200{ }^{\circ} \mathrm{C}$ with a heating/cooling rate of $5{ }^{\circ} \mathrm{C} / \mathrm{min}$, the weight gain was more than $9 \%$ [41]. TGA curves of our materials showed weight increase from $0.59 \%$ to $2.19 \%$ during the cooling cycle in $\mathrm{CO}_{2}$. Actually the small increase in weight does not mean the samples are unstable. So we put the TGA samples in $\mathrm{CO}_{2}$ atmosphere for duration of 10 days and repeated the XRD to check the stability. In XRD patterns no extra or impurity peak was found after TGA and hence the materials are stable. For unstable case, materials will decompose to $\mathrm{BaCO}_{3}$ in $\mathrm{CO}_{2}$ atmosphere and $\mathrm{XRD}$ peaks would differ (before and after TGA). Actually the smaller weight gain is better but the weight gains in these samples are within the limit.

Since BCZYZ samples have no extra peak, it is highly stable. Below the carbonation, say up to 800 ${ }^{\circ} \mathrm{C}$, heating a proton conducting electrolyte material in $\mathrm{CO}_{2}$ is not a good representative for its chemical stability testing and that's why several recognized proton conducting electrolyte materials like BZCY and BZCYYb were primarily reported to be stable in $\mathrm{CO}_{2}$, but later when tested at higher temperatures were found to be unstable [12], [56], [60]. Hence it is vital to test chemical stability in $\mathrm{CO}_{2}$ up to $1000{ }^{\circ} \mathrm{C}$ for proton conductors. 


\section{Conclusions}

The X-ray diffraction patterns of $\mathrm{BCZYZ}$ confirm that the samples are in single phase orthorhombic perovskite structure with Pbnm space group and high relative density and its sintering temperature is lower $\left(1200{ }^{\circ} \mathrm{C}\right)$. The SEM images show that the materials are highly dense and having larger morphology. The TGA and TMA analyses show that the samples are stable in nature, indicate that the samples prepared in the solid state reaction successfully completed at this temperature. The particle size distribution shows that the increase in $\mathrm{Zn}$ content decreases the size of the particle. The $\mathrm{Zn}$ addition has a very significant effect for improving the densification, grain morphology and lowering the sintering temperature; the optimum percentage of doping was $10 \mathrm{wt}$ $\%$ and higher addition of $\mathrm{Zn}$ decreases the conductivity. In wet hydrogen atmosphere the total conductivity of BCZYZ 2 is $8.6 \times 10^{-3} \mathrm{~S} \mathrm{~cm}^{-1}$ at $600{ }^{\circ} \mathrm{C}$ which is good for applications in ITSOFCs. It might be used as promising proton-conducting electrolyte for other electrochemical devices as well.

\section{Acknowledgments}

The authors S. Hossain and A. M. Abdalla are grateful to the graduate studies office of Universiti Brunei Darussalam for graduate research scholarship (GRS) for funding this research. The authors are thankful to Professor John T. S. Irvine for managing a visiting scholarship for SH and AMA at Center for Advanced Materials at School of Chemistry in University of St Andrews, UK for the research works done.

\section{References}

[1] R. Haugsrud and T. Norby, "Proton conduction in rare-earth ortho-niobates and orthotantalates," Nat. Mater., vol. 5, no. 3, pp. 193-196, Mar. 2006.

[2] E. Fabbri, D. Pergolesi, and E. Traversa, "Materials challenges toward proton conducting oxide fuel cells: a critical review," Chem. Soc. Rev., vol. 39, no. 11, pp. 4355-4369, 2010. 
[3] S. Hossain, A. M. Abdalla, S. N. B. Jamain, J. H. Zaini, and A. K. Azad, "A review on proton conducting electrolytes for clean energy and intermediate temperature-solid oxide fuel cells," Renew. and Sustain. Ener. Rev., vol. 79, pp. 750-764, 2017.

[4] C. Duan, J. Tong, M. Shang, S. Nikodemski, M. Sanders, S. Ricote, A. Almansoori, and R. O’Hayre, "Readily processed protonic ceramic fuel cells with high performance at low temperatures," Sci. , vol. 349, no. 6254, pp. 1321-1326, Sep. 2015.

[5] R. N. Karnik, "Materials science: Breakthrough for protons,” Nature, vol. 516, no. 7530, pp. 173-175, Dec. 2014.

[6] A. M. Abdalla, S. Hossain, A. T. Azad, P. M. I. Petra, F. Begum, S. G. Eriksson, and A. K. Azad, "Nanomaterials for solid oxide fuel cells: A review," Renew. and Sustain. Ener. Rev., vol. 82, no. September 2016, pp. 353-368, 2018.

[7] Z. Shi, W. Sun, and W. Liu, "Synthesis and characterization of $\mathrm{BaZr}_{0.3} \mathrm{Ce}_{0.5} \mathrm{Y}_{0.2-\mathrm{x}} \mathrm{Yb}_{\mathrm{x}} \mathrm{O}_{3-\delta}$ proton conductor for solid oxide fuel cells," J. Power Sources, vol. 245, pp. 953-957, Jan. 2014.

[8] T. Somekawa, Y. Matsuzaki, M. Sugahara, Y. Tachikawa, H. Matsumoto, S. Taniguchi, and K. Sasaki, "Physicochemical properties of $\mathrm{Ba}(\mathrm{Zr}, \mathrm{Ce}) \mathrm{O}_{3-\delta}$-based proton-conducting electrolytes for solid oxide fuel cells in terms of chemical stability and electrochemical performance," Int. J. Hydrogen Energy, vo. 42, issue 26, pp. 16722-16730, 2017.

[9] L. Fan, H. Xie, and P.-C. Su, "Spray coating of dense proton-conducting $\mathrm{BaCe}_{0.7} \mathrm{Zr}_{0.1} \mathrm{Y}_{0.2} \mathrm{O}_{3}$ electrolyte for low temperature solid oxide fuel cells," Int. J. Hydrogen Energy, vol. 41, no. 15, pp. 6516-6525, 2016.

[10] K. Katahira, Y. Kohchi, T. Shimura, and H. Iwahara, "Protonic conduction in Zr-substituted $\mathrm{BaCeO}_{3}, "$ Solid State Ionics, vol. 138, no. 1-2, pp. 91-98, 2000.

[11] A. K. Azad and J. T. S. Irvine, "High density and low temperature sintered proton conductor 
$\mathrm{BaCe}_{0.5} \mathrm{Zr}_{0.35} \mathrm{Sc}_{0.1} \mathrm{Zn}_{0.05} \mathrm{O}_{3-\delta}, "$ Solid State Ionics, vol. 179, no. 19-20, pp. 678-682, 2008.

[12] R. Kannan, K. Singh, S. Gill, T. Fürstenhaupt, and V. Thangadurai, "Chemically stable proton conducting doped $\mathrm{BaCeO}_{3}$-no more fear to SOFC wastes.," Sci. Rep., vol. 3, issue 1, p. $2138,2013$.

[13] N. S. Patki, S. Ricote, and J. D. Way, "Fabrication of reducing atmosphere electrodes (fuel electrodes) by electroless plating of copper on $\mathrm{BaZr}_{0.9-\mathrm{x}} \mathrm{Ce}_{\mathrm{x}} \mathrm{Y}_{0.1} \mathrm{O}_{3-\delta} \mathrm{A}$ proton-conducting ceramic,” Int. J. Hydrogen Energy, vol. 42, issue 27, pp. 16911-16919, 2017.

[14] J. Lv, L. Wang, D. Lei, H. Guo, and R. V Kumar, "Sintering, chemical stability and electrical conductivity of the perovskite proton conductors $\mathrm{BaCe}_{0.45} \mathrm{Zr}_{0.45} \mathrm{M}_{0.1} \mathrm{O}_{3-\delta}(\mathrm{M}=\mathrm{In}$, Y, Gd, Sm)," J. Alloys Compd., vol. 467, no. 1-2, pp. 376-382, 2009.

[15] A. K. Azad and J. T. S. Irvine, "Synthesis, chemical stability and proton conductivity of the perovksites $\mathrm{Ba}(\mathrm{Ce}, \mathrm{Zr})_{(1-\mathrm{x})} \mathrm{Sc}_{-\mathrm{x}} \mathrm{O}_{3-\delta}$, , Solid State Ionics, vol. 178, no. 7-10, pp. 635-640, 2007.

[16] P. Sawant, S. Varma, B. N. Wani, and S. R. Bharadwaj, "Synthesis, stability and conductivity of $\mathrm{BaCe}_{0.8-\mathrm{x}} \mathrm{Zr}_{\mathrm{x}} \mathrm{Y}_{0.2} \mathrm{O}_{3-\delta}$ as electrolyte for proton conducting SOFC," Int. J. Hydrogen Energy, vol. 37, no. 4, pp. 3848-3856, 2012.

[17] I. Ahmed, M. Karlsson, S.-G. Eriksson, E. Ahlberg, C. S. Knee, K. Larsson, A. K. Azad, A. Matic, and L. Börjesson, "Crystal Structure and Proton Conductivity of $\mathrm{BaZr}_{0 .}{ }_{9} \mathrm{Sc}_{0.1} \mathrm{O}_{3-\delta}$," J. Am. Ceram. Soc., vol. 91, no. 9, pp. 3039-3044, 2008.

[18] A. Slodczyk, M. Sharp, S. Upasen, P. Colomban, and J. Kilner, "Combined buck and surface analysis of the $\mathrm{BaCe}_{0.5} \mathrm{Zr}_{0.3} \mathrm{Y}_{0.16} \mathrm{Zn}_{0.04} \mathrm{O}_{3-\delta}$ ceramic proton conducting electrolyte," Solid State Ionics, vol. 262, pp. 870-874, 2014.

[19] E. Fabbri, A. D’Epifanio, E. Di Bartolomeo, S. Licoccia, and E. Traversa, "Tailoring the chemical stability of $\mathrm{Ba}\left(\mathrm{Ce}_{0.8-\mathrm{x}} \mathrm{Zr}_{\mathrm{x}}\right) \mathrm{Y}_{0.2} \mathrm{O}_{3-\delta}$ protonic conductors for Intermediate 
Temperature Solid Oxide Fuel Cells (IT-SOFCs)," Solid State Ionics, vol. 179, no. 15-16, pp. 558-564, 2008.

[20] H. Matsumoto, Y. Kawasaki, N. Ito, M. Enoki, and T. Ishihara, "Relation Between Electrical Conductivity and Chemical Stability of $\mathrm{BaCeO}_{3}$-Based Proton Conductors with Different Trivalent Dopants," Electrochem. Solid-State Lett., vol. 10, no. 4, pp. B77-80, 2007.

[21] A. K. Azad, A. Kruth, and J. T. S. Irvine, "Influence of atmosphere on redox structure of $\mathrm{BaCe}_{0.9} \mathrm{Y}_{0.1} \mathrm{O}_{2.95}$ - Insight from neutron diffraction study," Int. J. Hydrogen Energy, vol. 39, no. 24, pp. 12804-12811, Aug. 2014.

[22] H. G. Bohn and T. Schober, "Electrical conductivity of the high-temperature proton conductor $\mathrm{BaZr}_{0.9} \mathrm{Y}_{0.1} \mathrm{O}_{2.95}$," J. Am. Ceram. Soc., vol. 83, issue 4, pp. 768-772, 2000.

[23] F. M. M. Snijkers, A. Buekenhoudt, J. Cooymans, and J. J. Luyten, "Proton conductivity and phase composition in $\mathrm{BaZr}_{0.9} \mathrm{Y}_{0.1} \mathrm{O}_{3-\delta}$," Scr. Mater., vol. 50, issue 5, pp. 655-659, 2004.

[24] D. A. Stevenson, N. Jiang, R. M. Buchanan, and F. E. G. Henn, "Characterization of Gd, Yb and $\mathrm{Nd}$ doped barium cerates as proton conductors," Solid State Ionics, vol. 62, no. 3-4, pp. $279-285,1993$.

[25] A. K. Azad, D. D. Y. Setsoafia, L. C. Ming, and P. M. I. Petra, "Synthesis and characterization of high density and low temperature sintered proton conductor $\mathrm{BaCe}_{0.5} \mathrm{Zr}_{0.35} \mathrm{In}_{0.1} \mathrm{Zn}_{0.05} \mathrm{O}_{3-\delta}$, , Adv. Mater. Res., vol. 1098, pp. 104-109, 2015.

[26] K.-R. Lee, C.-J. Tseng, J.-K. Chang, I.-M. Hung, J.-C. Lin, and S.-W. Lee, "Strontium doping effect on phase homogeneity and conductivity of $\mathrm{Ba}_{1-\mathrm{x}} \mathrm{Sr}_{\mathrm{x}} \mathrm{Ce}_{0.6} \mathrm{Zr}_{0.2} \mathrm{Y}_{0.2} \mathrm{O}_{3-\delta}$ protonconducting oxides," Int. J. Hydrogen Energy, vol. 38, issue 25, pp. 11097-11103 2013.

[27] J. H. Kim, Y. M. Kang, B. G. Kim, S. H. Lee, and K. T. Hwang, "Preparation of dense composite membrane with Ba-cerate conducting oxide and rapidly solidified Zr-based 
alloy," Int. J. Hydrogen Energy, vol. 36, no. 16, pp. 10129-10135, 2011.

[28] T. Somekawa, Y. Matsuzaki, Y. Tachikawa, H. Matsumoto, S. Taniguchi, and K. Sasaki, "Physicochemical properties of proton-conductive $\mathrm{Ba}\left(\mathrm{Zr}_{0.1} \mathrm{Ce}_{0.7} \mathrm{Y}_{0.1} \mathrm{Yb}_{0.1}\right) \mathrm{O}_{3-\delta}$ solid electrolyte in terms of electrochemical performance of solid oxide fuel cells," Int. $J$. Hydrogen Energy, vol. 41, issue 39, pp. 17539-17547, 2017.

[29] Y. Guo, R. Ran, Z. Shao, and S. Liu, "Effect of Ba nonstoichiometry on the phase structure, sintering, electrical conductivity and phase stability of $\mathrm{Ba}_{1 \pm x} \mathrm{Ce}_{0.4} \mathrm{Zr}_{0.4} \mathrm{Y}_{0.2} \mathrm{O}_{3-\delta}(0 \leq \mathrm{x} \leq 0.20)$ proton conductors," Int. J. Hydrogen Energy, vol. 36, no. 14, pp. 8450-8460, 2011.

[30] L. Zhao, D. Ding, L. Zhang, L. Gui, Z. Wang, Y. Wan, R. Wang, Y. Ling, and B. He, “The effect of $\mathrm{Cr}$ deposition and poisoning on $\mathrm{BaZr}_{0.1} \mathrm{Ce}_{0.7} \mathrm{Y}_{0.2} \mathrm{O}_{3-\delta}$ proton conducting electrolyte," Int. J. Hydrogen Energy, vol. 39, no. 32, pp. 18379-18384, 2014.

[31] H. G. Bohn and T. Schober, "Electrical Conductivity of the High-Temperature," J. Am. Ceram. Soc., vol. 72, no. 189302, pp. 768-772, 2000.

[32] K. H. Ryu and S. M. Haile, "Chemical stability and proton conductivity of doped $\mathrm{BaCeO}_{3}$ $\mathrm{BaZrO}_{3}$ solid solutions," Solid State Ionics, vol. 125, no. 1, pp. 355-367, 1999.

[33] J. X. Wang, L. P. Li, B. J. Campbell, Z. Lv, Y. Ji, Y. F. Xue, and W. H. Su, "Structure, thermal expansion and transport properties," Mater. Chem. Phys., vol. 86, no. 1, pp. 150$155,2004$.

[34] H. Iwahara, H. Uchida, and K. Morimoto, "High Temperature Solid Electrolyte Fuel Cells Using Perovskite-Type Oxide Based on $\mathrm{BaCeO}_{3}$ Anode," J. Electrochem. Soc., vol. 137, no. 2, pp. 462-465, 1990.

[35] A. K. Azad, C. Savaniu, S. Tao, S. Duval, P. Holtappels, R. M. Ibberson, and J. T. S. Irvine, "Structural origins of the differing grain conductivity values in $\mathrm{BaZr}_{0.9} \mathrm{Y}_{0.1} \mathrm{O}_{2.95}$ and 
indication of novel approach to counter defect association," J. Mater. Chem., vol. 18, no. 29, pp. 3414-3418, 2008.

[36] H. Wang, R. Peng, X. Wu, J. Hu, and C. Xia, "Sintering behavior and conductivity study of yttrium-doped $\mathrm{BaCeO}_{3}-\mathrm{BaZrO}_{3}$ solid solutions using $\mathrm{ZnO}$ additives," J. Am. Ceram. Soc., vol. 92, issue 11, pp. 2623-2629, 2009.

[37] E. Gorbova, V. Maragou, D. Medvedev, A. Demin, and P. Tsiakaras, "Influence of sintering additives of transition metals on the properties of gadolinium-doped barium cerate," Solid State Ionics, vol. 179, issue 21-26, pp. 887-890, 2008.

[38] P. Babilo and S. M. Haile, "Enhanced sintering of yttrium-doped barium zirconate by addition of ZnO,” J. Am. Ceram. Soc., vol. 88, no. 9, pp. 2362-2368, 2005.

[39] B. Lin, M. Hu, J. Ma, Y. Jiang, S. Tao, and G. Meng, "Stable, easily sintered $\mathrm{BaCe}_{0.5} \mathrm{Zr}_{0.3} \mathrm{Y}_{0.16} \mathrm{Zn}_{0.04} \mathrm{O}_{3-\delta}$ electrolyte-based protonic ceramic membrane fuel cells with $\mathrm{Ba}_{0.5} \mathrm{Sr}_{0.5} \mathrm{Zn}_{0.2} \mathrm{Fe}_{0.8} \mathrm{O}_{3-\delta}$ perovskite cathode," J. Power Sources, vol. 183, issue 2, pp. 479484, 2008.

[40] S. Tao and J. T. S. Irvine, "A stable, easily sintered proton-conducting oxide electrolyte for moderate-temperature fuel cells and electrolyzers," Adv. Mater., vol. 18, no. 12, pp. 1581$1584,2006$.

[41] S. Tao and J. T. S. Irvine, "Conductivity studies of dense yttrium-doped $\mathrm{BaZrO}_{3}$ sintered at $1325{ }^{\circ}$ C,” J. Solid State Chem., vo. 180, issue 12, pp. 3493-3503, 2007.

[42] C. J. Zhang, H. L. Zhao, N. S. Xu, X. Li, and N. Chen, "Influence of ZnO addition on the properties of high temperature proton conductor $\mathrm{Ba}_{1.03} \mathrm{Ce}_{0.5} \mathrm{Zr}_{0.4} \mathrm{Y}_{0.1} \mathrm{O}_{3-\delta}$ synthesized via citrate-nitrate method," Int. J. Hydrogen Energy, vol. 34, issue 6, pp. 2739-2746, 2009.

[43] X. Lu, Y. Ding, and Y. Chen, " $\mathrm{Ba}_{0.5} \mathrm{Sr}_{0.5} \mathrm{Zn}_{0.2} \mathrm{Fe}_{0.8} \mathrm{O}_{3-\delta}-\mathrm{BaCe}_{0.5} \mathrm{Zr}_{0.3} \mathrm{Y}_{0.16} \mathrm{Zn}_{0.04} \mathrm{O}_{3-\delta}$ composite cathode for proton-conducting solid oxide fuel cells," J. Alloys Compd., vol. 484, no. 1-2, 
pp. 856-859, 2009.

[44] H. Iwahara, T. Yajima, T. Hibino, K. Ozaki, and H. Suzuki, "Protonic conduction in calcium, strontium and barium zirconates," Solid State Ionics, vol. 61, no. 1-3, pp. 65-69, May 1993.

[45] N. Bonanos, "Transport properties and conduction mechanism in high-temperature protonic conductors,” Solid State Ionics, vol. 53-56, issue part 2, pp. 967-974, 1992.

[46] A. Afif, N. Radenahmad, C. M. Lim, M. I. Petra, M. A. Islam, S. M. H. Rahman, S. Eriksson, and A. K. Azad, "Structural study and proton conductivity in $\mathrm{BaCe}_{0.7} \mathrm{Zr}_{0.25-\mathrm{x}} \mathrm{Y}_{\mathrm{x}} \mathrm{Zn}_{0.05} \mathrm{O}_{3}(\mathrm{x}=0.05,0.1,0.15,0.2$ \&amp; 0.25)," Int. J. Hydrogen Energy, vol. 41, no. 27, pp. 11823-11831, 2016.

[47] K. R. Lee, C. J. Tseng, J. K. Chang, K. W. Wang, Y. S. Huang, T. C. Chou, K. C. Chiu, L. D. Tsai, and S. W. Lee, " $\mathrm{Ba}_{1-\mathrm{x}} \mathrm{Sr}_{\mathrm{x}} \mathrm{Ce}_{0.8-\mathrm{y}} \mathrm{Zr}_{\mathrm{y}} \mathrm{Y}_{0.2} \mathrm{O}_{3-\delta}$ protonic electrolytes synthesized by hetero-composition-exchange method for solid oxide fuel cells," Int. J. Hydrogen Energy, vol. 42, issue 34, pp. 22222-22227, 2017.

[48] N. Nasani, P. A. N. Dias, J. A. Saraiva, and D. P. Fagg, "Synthesis and conductivity of $\mathrm{Ba}(\mathrm{Ce}, \mathrm{Zr}, \mathrm{Y}) \mathrm{O}_{3-\delta}$ electrolytes for PCFCs by new nitrate-free combustion method," Int. J. Hydrogen Energy, vol. 38, issue 20, pp. 8461-8470, 2013.

[49] P. E. Werner, L. Eriksson, and M. Westdahl, "TREOR, a semi-exhaustive trial-and-error powder indexing program for all symmetries," J. Appl. Crystallogr., vol. 18, no. 5, pp. 367$370,1985$.

[50] J. Lougier and B. Bochu, “Checkcell: Graphical Powder Diffraction Indexing Cell and Space Group Assignment Software.”

[51] J. Rodriguez-Carvajal, "Recent advances in magnetic structure determination by neutron powder diffraction + FullProf," Phys. B Condens. Matter, vol. 192, no. 1--2, p. Pages--55, 
1993.

[52] D. Pergolesi, E. Fabbri, A. D’Epifanio, E. Di Bartolomeo, A. Tebano, S. Sanna, S. Licoccia, G. Balestrino, and E. Traversa, "High proton conduction in grain-boundary-free yttriumdoped barium zirconate films grown by pulsed laser deposition," Nat. Mater., vol. 9, no. 10, pp. 846-852, 2010.

[53] Y. Li, R. Guo, C. Wang, Y. Liu, Z. Shao, J. An, and C. Liu, "Stable and easily sintered $\mathrm{BaCe}_{0.5} \mathrm{Zr}_{0.3} \mathrm{Y}_{0.2} \mathrm{O}_{3-\delta}$ electrolytes using $\mathrm{ZnO}$ and $\mathrm{Na}_{2} \mathrm{CO}_{3}$ additives for protonic oxide fuel cells," Electrochim. Acta, vol. 95, pp. 95-101, 2013.

[54] B. Mirfakhraei, F. Ramezanipour, S. Paulson, V. Birss, and V. Thangadurai, "Effect of Sintering Temperature on Microstructure, Chemical Stability, and Electrical Properties of Transition Metal or $\mathrm{Yb}$-Doped $\mathrm{BaZr}_{0.1} \mathrm{Ce}_{0.7} \mathrm{Y}_{0.1} \mathrm{M}_{0.1} \mathrm{O}_{3-\delta}(\mathrm{M}=\mathrm{Fe}, \mathrm{Ni}, \mathrm{Co}$, and $\mathrm{Yb})$," Front. Energy Res., vol. 2, p. 9, 2014.

[55] L. Bi, Z. Tao, C. Liu, W. Sun, H. Wang, and W. Liu, "Fabrication and characterization of easily sintered and stable anode-supported proton-conducting membranes," J. Memb. Sci., vol. 336, issue 1-2, pp. 1-6, 2009.

[56] C. D. Zuo, S. W. Zha, M. L. Liu, M. Hatano, and M. Uchiyama, " $\mathrm{Ba}\left(\mathrm{Zr}_{0.1} \mathrm{Ce}_{0.7} \mathrm{Y}_{0.2}\right) \mathrm{O}_{3-\delta}$ delta as an electrolyte for low-temperature solid-oxide fuel cells," Adv. Mater., vol. 18, issue 24, pp. 3318-3320, 2006.

[57] L. Yang, S. Wang, K. Blinn, M. Liu, Z. Liu, Z. Cheng, and M. Liu, "Enhanced Sulfur and Coking Tolerance of a Mixed Ion Conductor for SOFCs: $\mathrm{BaZr}_{0.1} \mathrm{Ce}_{0.7} \mathrm{Y}_{0.2-\mathrm{x}} \mathrm{Yb}_{\mathrm{x}} \mathrm{O}_{3-\delta}$," Sci. , vol. 326, no. 5949, pp. 126-129, Oct. 2009.

[58] X. Zhou, L. Liu, J. Zhen, S. Zhu, B. Li, K. Sun, and P. Wang, "Ionic conductivity, sintering and thermal expansion behaviors of mixed ion conductor $\mathrm{BaZr}_{0.1} \mathrm{Ce}_{0.7} \mathrm{Y}_{0.1} \mathrm{Yb}_{0.1} \mathrm{O}_{3-\delta}$ prepared by ethylene diamine tetraacetic acid assisted glycine nitrate process," J. Power Sources, vol. 
196, issue 11, pp. 5000-5006, 2011.

[59] N. Agmon, "The Grotthuss mechanism," Chem. Phys. Lett., vol. 244, issue 5-6, pp. 456-462, 1995.

[60] I. Ahmed, C. S. Knee, M. Karlsson, S.-G. Eriksson, P. F. Henry, A. Matic, D. Engberg, and L. Börjesson, "Location of deuteron sites in the proton conducting perovskite $\mathrm{BaZr}_{0.50} \mathrm{In}_{0.50} \mathrm{O}_{3-\delta}, "$ J. Alloys Compd., vol. 450, no. 1-2, pp. 103-110, 2008.

[61] A. K. Azad and J. T. S. Irvine, "Location of Deuterium Positions in the Proton-Conducting Perovskite $\mathrm{BaCe}_{0.4} \mathrm{Zr}_{0.4} \mathrm{Sc}_{0.2} \mathrm{O}_{2.90} \times \mathrm{xD}_{2} \mathrm{O}$ by Neutron Powder Diffraction," Chem. Mater., vol. 21, no. 2, pp. 215-222, Jan. 2009.

[62] M. S. Islam, P. R. Slater, J. R. Tolchard, and T. Dinges, "Doping and defect association in $\mathrm{AZrO}_{3}(\mathrm{~A}=\mathrm{Ca}, \mathrm{Ba})$ and $\mathrm{LaMO}_{3}(\mathrm{M}=\mathrm{Sc}, \mathrm{Ga})$ perovskite-type ionic conductors.," Dalton Trans., vol. 3, issue 19, pp. 3061-3066, 2004.

[63] S. V. Bhide, "Stability of $\mathrm{BaCeO}_{3}$-based proton conductors in water-containing atmospheres,” J. Electrochem. Soc., vol. 146, issue 6, p. 2038, 1999.

[64] E. Fabbri, L. Bi, H. Tanaka, D. Pergolesi, and E. Traversa, "Chemically stable Pr and Y Codoped barium zirconate electrolytes with high proton conductivity for intermediatetemperature solid oxide fuel cells," Adv. Funct. Mater., vol. 21, issue 1, pp. 158-166, 2011.

[65] S. Barison, M. Battagliarin, T. Cavallin, L. Doubova, M. Fabrizio, C. Mortalò, S. Boldrini, L. Malavasi, and R. Gerbasi, "High conductivity and chemical stability of $\mathrm{BaCe}_{1-\mathrm{x}-\mathrm{y}} \mathrm{Zr}_{\mathrm{x}} \mathrm{Y}_{\mathrm{y}} \mathrm{O}_{3-\delta}$ proton conductors prepared by a sol-gel method," J. Mater. Chem., vol. 18 , issue 42, p. 5120, 2008.

[66] S. Ricote, N. Bonanos, and G. Caboche, "Water vapour solubility and conductivity study of the proton conductor $\mathrm{BaCe}_{0.9-\mathrm{x}} \mathrm{Zr}_{\mathrm{x}} \mathrm{Y}_{0.1} \mathrm{O}_{3-\delta}$," Solid State Ionics, vol. 180, no. 14-16, pp. 990-997, 2009. 